\title{
Development of Tender Price Indices for the Ghanaian Building Industry
}

\author{
Ernest Kissi ${ }^{1}$, Theophilus Adjei-Kumi ${ }^{1}$, Jerry Gyimah Jnr ${ }^{2}$ \\ ${ }^{1}$ Department of Construction Technology and Management, Kwame Nkrumah University of Science and Technology, Kumasi, \\ Ghana \\ ${ }^{2}$ CSIR-Building and Road Research Institute, Kumasi, Ghana \\ Email: jerrygyimah13@gmail.com
}

How to cite this paper: Kissi, E., Adjei-Kumi, T. and Jnr, J.G. (2021) Development of Tender Price Indices for the Ghanaian Building Industry. Journal of Building Construction and Planning Research, 9 , 189-222.

https://doi.org/10.4236/jbcpr.2021.93013

Received: July 8, 2021

Accepted: July 30, 2021

Published: August 3, 2021

Copyright $\odot 2021$ by author(s) and Scientific Research Publishing Inc. This work is licensed under the Creative Commons Attribution-NonCommercial International License (CC BY-NC 4.0). http://creativecommons.org/licenses/by-nc/4.0/ (c) (i) (8) Open Access

\begin{abstract}
Tender price indices (TPI) remain an optimum process for predicting tender prices. There have been several indices' developments in the Ghanaian Building Industry (GBI) to help in cost management practices, for instance, building cost indices, and material indices among others. Notwithstanding, there are no indices for forecasting tender price at the design stage of building projects in the Ghanaian Building Industry. The motivation of this study is to develop tender price indices that would facilitate easy prediction of the initial cost of building projects. Through a thorough literature review and secondary data collection, the index was formulated using Laspeyres with Excel spreadsheet for the actual index. The variables considered include preliminaries and measured work sections which include the substructure, concrete work, reinforcement, masonry, lining/sheathing, window/door/stairs, metalwork, surface finishes, sanitary appliances/fitting and electrical supply/power light system of the Bills of Quantities. The finding of the study shows that on average there is a change in price of about 4.42 per cent within the eight-year period from 2008 to 2016. The study has developed tender price indices for the Ghanaian Building industry for the facilitation of the easy prediction of the tender prices at the initial design stage, however, the indices have an error margin of \pm 3 . The development of these indices will serve as the basis for further development of other indices in GBI such as locational indices and value-based indices for effective cost management practices.
\end{abstract}

\section{Keywords}

Building Industry, Development, Ghana, Tender Price Indices 


\section{Introduction}

Clients need to be notified in advance of their possible future financial commitments and cost consequences at the design advancement stage [1]. Quantity surveyors at an early stage of any project are mostly expected to provide a likely tender price for the client's specification. It is somewhat easy to modify the historical construction cost to those of current date by using suitable past TPI. Thus, it is often hard to prepare the current cost up to the date of tendering (i.e., the tender price) due to the unforeseen future market situation [2]. Though, a precise forecast of TPI in a few quarters ahead is very crucial for all inmates in the construction industry. Tender price index (TPI) is used for many practical purposes in the construction industry, including establishing the level of individual tenders, adjustment for time, pricing, cost planning, and forecasting cost trends and general comparisons [3]. It then reflects the expected market situations [4].

Consequently, TPI measures the tender price movements of the building industry, as it covers most of the items usually built into the price for providing the output of construction activity [5] [6] [7]. This helps clients to make a known decision. Accordingly, TPIs represent the cost a client has agreed to pay for a building and correspond to the price offer made by the contractor in the tender. However, in this study, TPI was approved as an output index of the average building prices within a specified period, i.e., the agreed price to be paid by the clients/owners [2]. Forecasting of the TPI is relevant to stakeholders in the construction industry as it reflects the trend of contractors' pricing in bills of quantities for approved tenders through the competitive tendering process [8]. It involves the appraisal of building costs, which is done based on cost data updated by the forecast tender price index ([1] [3] [9]). The price reflects the contractor's opinions about future costs for labour and materials and their expectation of the market's effect on profit margins. TPIs are built by comparing the prices of a proportion of the items within a sample of approved tenders in a timeframe against the price of likely items in a base schedule of rates. It denotes constituents of the reducers used to obtain the building industry's real new output price indices [10]. The indices are computed for each tender within the sample and the average is taken to give the final index for that time being. Hence, different sources of information can be used in producing indices but depending on the market conditions, but the constructing methods resemble. The correctness of the tender price index is a result of their use and form, time horizon and data availability ([11] [12]). TPI is usually used for the following:

- Compressing of building sector components of the nominal national product,

- Checking relative price change and inflation in the building industry for evaluation and anticipating of market conditions,

- Reviewing historical cost data for cost planning and estimating, and

- International comparisons of the level and growth.

In Ghana, the commonly used indices are the GBI which is an input index. 
These are the local price adjustment factor (LPAF) published by Construction Industry Efficiency Improvement Group of Ghana (CIECG-G), construction price adjustment formula published by the Ministry of Roads and Transportation for use in road contracts, prime building cost index (PBCI) published by the Ghana Statistical Service and used basically for building works, and Construction Cost Indices (CCI) by Building and Road Research Institute.

Notwithstanding, the development of these indices and their contribution to cost management practices in GBI, there have been no studies for the development of any output indices. As a result, [13] reiterated that some building cost experts in Ghana are unable to provide quality and reliable estimates due to lack of an effective tool for cost planning. However, this problem is partly due to the lack of tender price indices in the construction industry of Ghana. Similarly, [14] as cited by [15] argued that in Ghana and most developing countries, no organization has endeavoured to publish and accumulate construction data which leads to the unattainability of such information as a result the pricing and planning of projects are stalled. Consequently, if a construction firm fails to win a contract, the resources they invested are wasted. On the other hand, if clients do not have the knowledge or forecast on how much they are expected to invest in a project, they become reluctant to invest. More importantly, if consultants also fail to give a realistic price for tender, they lose credibility. Hence, it is paramount for stakeholders in construction to provide suitable tender prices for intended projects based on previous tenders.

In developed countries, such as, Hong Kong, the USA and the UK, there are established institutions such as the Building Cost Information Service of the United Kingdom, Architectural Service Department of Hong Kong and Engineering News Records of the United States of America who engage in the development of tender prices and locational indices. Notwithstanding, construction professionals in developing countries are not able to adapt their end products because of the extent of influence that cultural difference has on their decisions. These cultural differences are related to the values, attitudes, and norms that will not work in developing countries such as Ghana ([16] [17]). In the same way, [18] opined that it is not an easy task to adopt or keep up a scientific strategy to measure decisions that work in one country to another due to the difficulty and diversity of construction administrations that exist in different countries.

Furthermore, cost management of construction projects involves data collection, cost estimation, cost budgeting and cost monitoring and control [19]. These processes are repeatedly undertaken during each project phase of the project life cycle. However, there is a need to check the accuracy of estimates at every stage of the project based on the information available. Hence, various estimates are produced based on the project life cycle development. For instance, the design estimate deals with the conceptual stage, preliminary design stage, detailed design stage, the pre-contract estimate deal with tendering stage and contracting stage and the post-contract estimate with the construction stage (Ibid). This research is therefore concerned with cost management at the preliminary design 
stage. Traditionally, the practice of a Quantity Surveyor depends heavily on data on previous and similar projects to predict the preliminary estimate of a future project. The design team usually adopts one of the two approaches namely costing to design and designing to cost. In costing to design, the design decisions are made by the design professionals while the quantity surveyor determines the cost decision. This is inappropriate as any cost overruns will be very difficult and expensive to correct. On the other hand, design to the cost is the most favoured as normally referred to as cost planning or elemental cost planning. In this approach, accuracy depends on the use of similar and previous projects as basis. The cost data or cost analysis of the historical project is transposed to the future time frame within which the current project will be constructed using indices called TPI. This transposed cost analysis is then further adjusted for quality, location quantity among others and the results are used to prepare the cost plan of the future project. This plan is called the elemental plan since the cost of the project will be distributed among the various elements as presented by the Standard Form Cost Analysis (SFCA) by the RICS, UK. The designer will then commence designing and at each stage the QS will evaluate the design decision and educate the professional accordingly. In all these the TPI stands out as very crucial in dealing with historical data. The index is statistic that means the relative changes in the levels of the tender prices of a project over time. In Ghana, a former colony of the UK has accepted the QS as the cost professional of the design team and its system is similar to that of the UK. Unfortunately, the processes leading to the early determination of the project cost are not well-practised and documented in the Ghanaian situation. Although cost analysis of projects can be accurately prepared based on SFCA of the RICS, TPIs needed to transpose cost figures within the time frames do not exist. The practice of elemental cost planning is therefore hampered by this situation.

It is against the above stated situation that this study is being conducted. The aim of this study is therefore to develop tender price indices to provide the information for effective cost estimating of the building projects in Ghana. The outcome of this study will enable stakeholders to appreciate the need of TPI in the Ghanaian Building Industry as well as provide them with the methodology to produce TPI to enable them to produce accurate cost estimates of tenders.

\section{TPI Development}

In developing TPI, the first two main factors to be considered before the construction of the indices are the selection of the constituent items and the choice of their weights ([10] [20]). The analysis of these was based on the Standard Method of Measurement (SMM5, SMM6 and SMM7) and standard contract documents used in the Ghanaian building industry. In addition, the indices were developed based on the accepted tenders of already priced Bills of Quantities for contractors. It is worthy to note that, these of BOQs reflect the actual pricing strategies adopted by contractors in the Ghanaian Building Industry and upon 
this basis contracts are awarded. On this basis, the following steps were adopted to achieve the development of tender price indices.

\section{Constituent Items of Bill of Quantities}

The constituent items that were considered were based on items that were priced in the Bill of Quantities (BOQ). These include:

- Preliminaries,

- Measured Works Section (Building Works),

- Provisional Sum or Prime Cost Sums,

- Contingency Sum, and

- Value Added Tax (VAT) and National Health Insurance Levy.

\subsection{Preliminaries}

Preliminaries are general work items that are not necessarily related to any permanent work items [21]. Preliminaries are estimated as method-related charges and divided into time-related and fixed charges. Preliminaries form a vital part of any contract and may vary between contracts as well as fluctuate within economic climates. For instance, [22] in developing TPI considered 5\% as the fixed amount per project while [20] considered the preliminaries as a percentage on each item in the BOQ which is also similar to British Cost Information Service (BCIS). On this basis, preliminaries were pro-rated and spread evenly among the various trade sections as a percentage for each project. This procedure provides uniformity in the sharing of the total sum of the preliminaries on all trade sections which automatically will influence the base rate of each item.

\subsection{Measured Works Section (Building Works)}

The measured work sections in BOQs for building works in Ghana deal with the main work sections which include the substructure, concrete work, reinforcement, masonry, lining/sheathing, window/door/stairs, metalwork, surface finishes, sanitary appliances/fitting and electrical supply/power light system. These sections are generally measured based on the Standard Method of Measurement in GBI.

\subsection{Provisional and Prime Cost Sums}

Provisional sums deal with the undefined or defined items which cannot be priced due to the inadequacy of information at the time of the preparation of the BOQ ([23] [24]). It is, therefore, the sum provided for work that is not completely designed but for which the following information is provided which includes the nature of construction work, statement of how and where the work is fixed to the building and what other works are to be fixed thereof and quantities which indicate scope and extent of work and any specific limitations [25]. In a study conducted by [22] and BCIS, allowances were not made for provisional sums, however, [20] argued that in South Africa a contract could have provisional sums ranging from $40 \%$ to $50 \%$ of the contract sum, hence it was consid- 
ered. However, in Ghana, there remains no established rule or percentage for the determination of provisional sum. In addition, the provisional sum remains a grey area in measurement practices where in some cases allowances are made or not made for some projects. It must be noted that provisional sums are mainly lump sums, hence, the calculation of a rate for each constituent item may be difficult and differ from one project to another. It was therefore excluded in the indices development.

Prime Cost (PC) sums to deal with defined and most often specialist items such as electrical and mechanical installations. However, [20] equates this to provisional sums due to the nature of the South Africa system of measurement where there is budgetary allowance application. Albeit, in this study Prime cost sums, were excluded due to the lump-sum nature they possess. However, it can be argued that the use of per square cost of the gross floor area can serve as the rate for PC. But getting gross area from BOQ to per square rate will not be reliable. For instance, [20] argued that it is not the ideal solution to deal with such a problem. [10] indicated that PC represents about $40 \%$ of the contract sum.

\subsection{Contingency Sum}

Contingency sums are the amount set aside by clients for unforeseen risk; its determination has always been a challenge to the consultant's team. From the perspective of the Project Management Institute [26] it is a fund budgeted or timed needed above the amount estimated to reduce the risk of overruns on project objectives to a level acceptable to an organisation. As a result, several models have been developed to predict contingencies, although these models have difficulties in giving an accurate result. According to [27], a perfect contingency sum must be close to the amount of project cost overrun. Contingencies are sometimes referred to as the sum for undefined work items. In Ghana, contingency sums range from $2.5 \%$ to $10 \%$ [28], but this percentage has not been accepted by construction professionals. Hence, arbitrary percentages are normally adopted for fixing contingencies based on past experiences, perceptions, and sometimes historical data without much scientific basis [29]. Drawing on the context of GBI, contingencies were not included because its computation was not based on scientific facts and was arbitrarily fixed. Allowances made in contracts are not based on realistic information and normally do not meet the needs of the unanticipated cost overruns.

\subsection{Value Added Tax (VAT) and National Health Insurance Levy (NHIL)}

Value Added Tax and National Health Insurance Levy form part of the constituent items in a standard BOQ which represent $14.5 \%$ and $2.5 \%$ of contract sums respectively. The Ghana Revenue Authority (GRA) in 2010 in consultation with the Ghana Institution of Surveyors began its implementation in 2011. This was based on the amended VAT Law, (Act 629) of 2002, which requires all contract works to attract VAT + NHIL. However, its implementation has been very challenging, because of the unsuitable methodology that includes modalities and 
procedures for its application ([30]). Furthermore, its application has not generated the anticipated results as most of the contractors and consultants within the industry are not registered for VAT ([30] [31]). In addition, the data that were used for this study spanned from 2008 to 2016, hence, VAT + NHIL was not considered in this study because the start date for its implementation is inconsistent with the start date of the data for the study. Consequently, even if it was considered, it will render the indices inaccurate as some years will not have the VAT + NHIL component. It is, worth noting that the VAT + NHIL component not included is the output VAT, not the input VAT.

\section{Research Methodology for Development of TPI}

Following the explanation of the constituent items in Bills of Quantities and its adjustment, this section outlines the procedures which were adopted to arrive at the TPI. The procedures are as follows:

- Determination of Samples of Bill of Quantities,

- Selection of Base Year, and

- Index Calculation (Laspeyres formulae were used in conjunction with an EXcel spreadsheet for the actual index).

\section{Determination of Samples of Bill of Quantities}

To determine the number of BOQs to be sampled for the study the following three procedures were followed:

- Deciding on the type of buildings, and

- Determining the sample size. Types of buildings

To establish the sample size for the indices there was the need to identify the type of buildings to be used. However, in Ghana, there are no statistics to back the average type of houses constructed within a year. [20] and [32] argued that the employment of an average type of buildings is a conventional technique for the computation of construction price indices. Notwithstanding, [33] as cited by [20] in developing the building cost index, estimated the following types of buildings warehouses, houses, offices, and flats. In similar studies, Norwegian residential houses were used [34], Hong Kong general buildings by their Architecture Service Department were used in 1970, Singapore residential and commercial office blocks were also used, and in South Africa average building types were used [20]. On the other hand, according to [10], BCIS sampled building projects on their monetary value basis, in this case, building projects with a value over $£ 100,000.00$ were used for the TPI development.

Drawing from the above and grounding the argument in the Ghanaian building industry, the study was based on building types to establish BOQs of projects to be used for the index development. It is worth noting that all Bills of Quantities were from contractors of classes D1K1 and D2K2. This is because it would offer high reliability in pricing when compared to D3K3 and D4K4 contractors. 
In buttressing this, $\mathrm{D} 3 \mathrm{~K} 3$ and $\mathrm{D} 4 \mathrm{~K} 4$ contractors over the years have been criticised for lacking technical and managerial expertise and inadequate financial standing ([13] [35] [36]) when compared to D1K1 and D2K2 contractors. Hence, it is obvious that these difficulties will affect their pricing strategies and level of credibility. Furthermore, projects of D1K1 and D2K2 contractors were chosen because of the nature of the projects they handled and the availability of reliable information.

The types of buildings that were considered for the study were non-residential buildings. A building is considered non-residential when a small portion of the building is used for dwelling purposes that are less than half of its gross floor area. In this study, the non-residential building types that were considered comprised educational buildings such as classrooms, administration blocks, office complexes, laboratories, libraries, and auditoriums. The reason ascribed to the non-usage of residential buildings is that residential houses tend moderate levels of specification when compared to other projects. Furthermore, all BOQs obtained for the analysis were for new projects, excluding additions and alterations.

Determining the sample size

The actual sample size of the sample of Bills of Quantities (BOQs) for TPI development continues to be a growing debate among researchers. [20] argued that construction literature is vague about the actual acceptable BOQs for the development of TPI. However, [10] argued that for BCIS a total of eighty (80) BOQ are sampled for each quarter which they believe are reliable for preparing TPI. The motive for the sample size of 80 projects is that approximately $90 \%$ of price indices of individual projects would be within the average of \pm 2.8 . However, in the study conducted by BCIS, they sampled a total of 67 BOQs from 1990 to 2005. Out of this, 37 were public sector non-housing building projects and these were used in developing all-in TPI. This was due to the shift from the traditional procurement system to the design and build [10] and drop-in construction activities [37]. The Department for Business Innovation and Skills also sampled 57 public non-housing projects on average in each quarter for its TPI [10].

The Department of Trade and Industry, UK (DTI) sampled 66 public non-housing building projects on average in each quarter over the same period for their public sector building non-housing TPI. In contrast, [37] reported that some chartered quantity surveying firms in the UK produce in-house TPIs, by using a sample size of 15 due to lack of an adequate number of BOQs and capacity. In South Africa, the Bureau for Economic Research (BER) argued that 40 projects were appropriate to have a stable index on yearly basis [22]. On the contrary, [38] argued that index values based on less than seven projects cannot be regarded as being statistically stable. In the same vein, [20] in South Africa sampled an average of 36 priced BOQs per year. The findings of this study show that the difference in the average percentage for the weighting of the various trade sections decreases as the number of projects increases. This indicates that 33 projects were reliable for good indices. 
From the above discussion, it can be deduced that there is no fixed requirement for the number of BOQs for TPI development, but the minimum should not be less than seven. Hence, in the current study $40 \mathrm{BOQs}$ are expected to be sampled per year using both purposive and random sampling techniques. Institutions that were involved in the data collection included Architectural and Engineering Services Limited and public tertiary institutions (ten (10) polytechnics and six (6) public universities).

\section{Selected base year}

The next step was to decide on the base year for calculating the index. However, according to Agarwal et al., (2009), the base period should be chosen within a period of relative economic stability with no strange incidences such as war, irregular climatic circumstances, serious economic recession, drought, flood or famine among others. [39] further opined that the base period should not be too far from the past because products can disappear from the market and new products are introduced in the period between the base period and the current period. Hence, the prescribed value for the base is usually 100 ([40] [41]). The reason for fixing the base year value at 100 is that it allows increase and decrease in the value of the data, therefore avoids any confusion of negative number when a decrease value falls below the base index number. Following this, the base year in this study was fixed at 2008 as it recorded a GDP growth rate of $9.1 \%$ higher than the previous year of 2007 and the subsequent year, 2009 [42]. In addition, the year 2008 recorded an improvement in construction contribution to GDP of 7.2 higher than the previous year, 2007 of 5.7 percent of GDP. Hence, the base year selected was suitable. The period under consideration was from 2008 to 2016.

\section{Formula Index Calculation}

This calculation follows the principles of the Laspeyres: this is given by calculating the base-year quantities at the current rate and then dividing it by the total of the base year quantities at the base year rate, all multiplied by 100 . This was done for each quarter of the study period.

Laspeyres price index was chosen because it takes into consideration the ratio of the total cost of purchasing a specified set of commodities (basket of goods) at current prices. It does not understate inflation within a particular year. More importantly, it needs less information as compared to other indices [43]. According to [44], Laspeyres is widely used due to its ability to apply the base weight which is similar to others.

\section{Data Analysis}

This section presents the data analysis for the various BOQs which were used for the establishment of the indices (see Figure 1 and Figure 2). It includes the following steps.

\subsection{Regional Influence}

Regional influence has an impact on the price of building projects as the price of 
Adjustment (BOQ - External

works, Preliminaries, PC

sum/Provisional/Contingency)

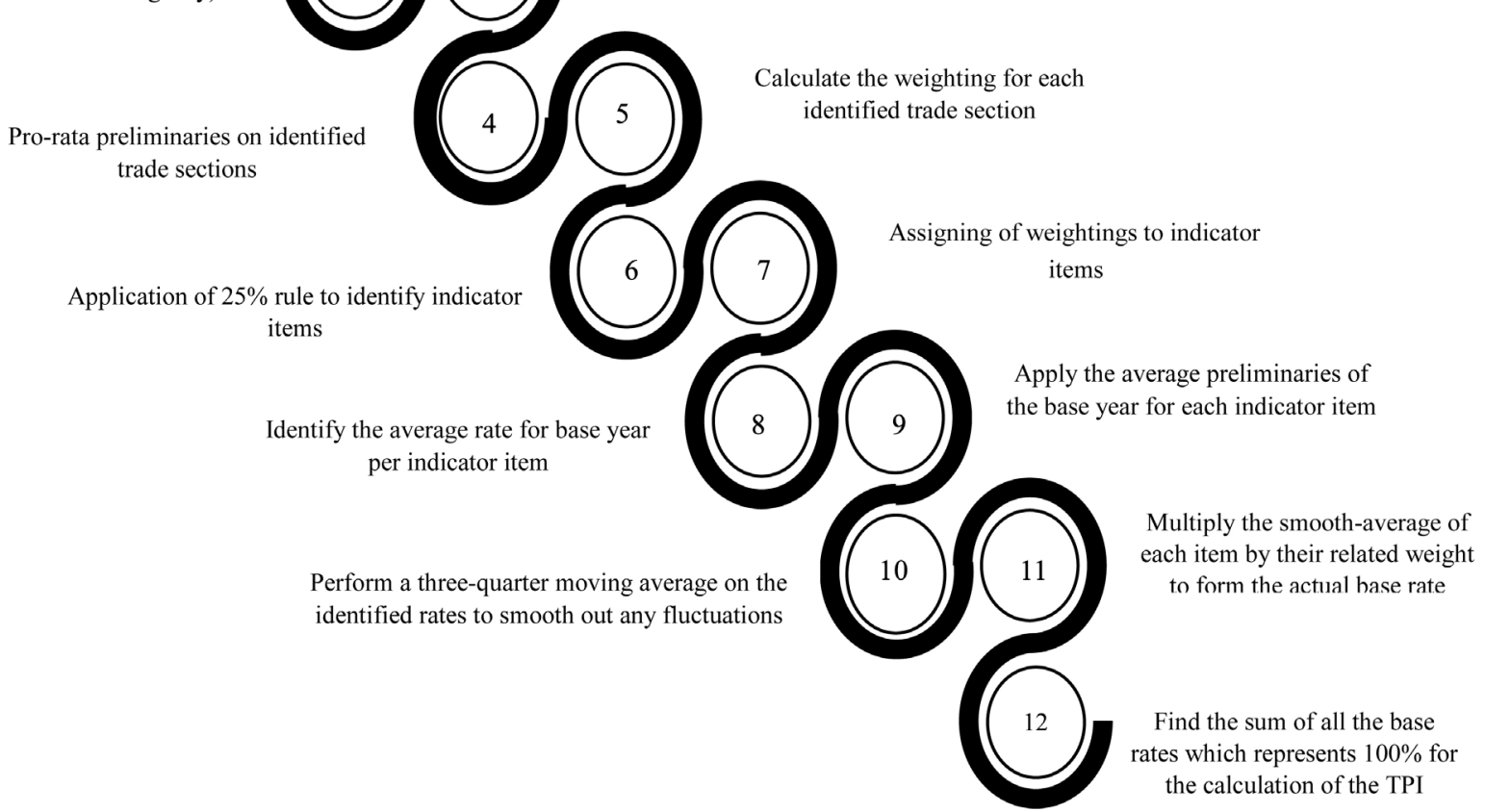

Figure 1. Flow chart of base index calculation.

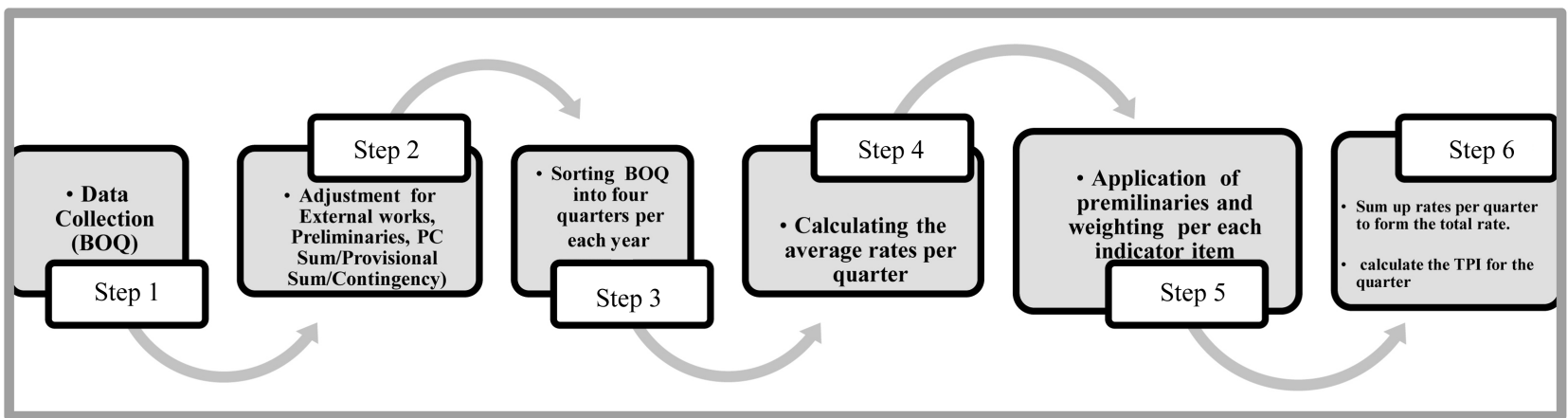

Figure 2. Flow chart of quarterly calculation of index.

materials differ from one location to another. Similarly, the nature of sites has some sort of impact on pricing. In considering the level of regional influence, the scope of data collection was expanded to cover all the ten main regions in Ghana, namely Greater Accra, Ashanti, Western, Northern, Brong-Ahafo, Eastern, Central, Volta, Upper East and Upper West. This helped to get the average unit rate of items. On the other hand, projects that were used for the indices have fairly uniform site conditions, that is, from the analysis, all the BOQs consisted of normal strip foundation hence, their influence was considered in the pricing. From the collation of the Priced Bills of Quantities from all the ten re- 
gional capitals, a total of 541 BOQs were collected as shown in Figure 3. Eastern Region records the highest number of BOQs (85), followed by Northern Region with 69 while Upper East Region and Upper West Region recorded the lowest values of 34 and 36 BOQs respectively. These results cannot be ascribed to any growing phenomena. The BOQs were given based on the willingness of the contacted offices of AESL, both public polytechnics and universities. Although, public infrastructure development may be tied to several factors, such as population growth, regional balances, the size of the region among others, the current study did not consider these factors.

\subsection{Sample Size}

BOQs are collated based on the period under consideration (2008-2016). On a whole, 2010 recorded the highest number of BOQs (115) followed by 2011 with 93 while 2013 and 2009 recorded the least values of 42 and 34 respectively (Figure 4). This occurrence can be attributed to politics in Ghana. Consequently, it is common knowledge that in our part of the world political seasons override public infrastructure and the level of spending by the central government. In line with this, [45] opined that governments all over the world have the authority to initiate or stop projects based on political factors. In making an inference from the field data which is shown in Figure 5 and during the election period of Ghana, it could clearly be deduced that during the election years (2008 and 2012) the government initiated more projects when compared to the immediate year after the election year (2009 and 2013).

On the other hand, it is interesting to note that during the second year of the then administration more projects were initiated (2010 and 2014). In addition, it was evident that after the second year, the initiation of projects significantly declined as the election year approaches to allow further concentration to ongoing

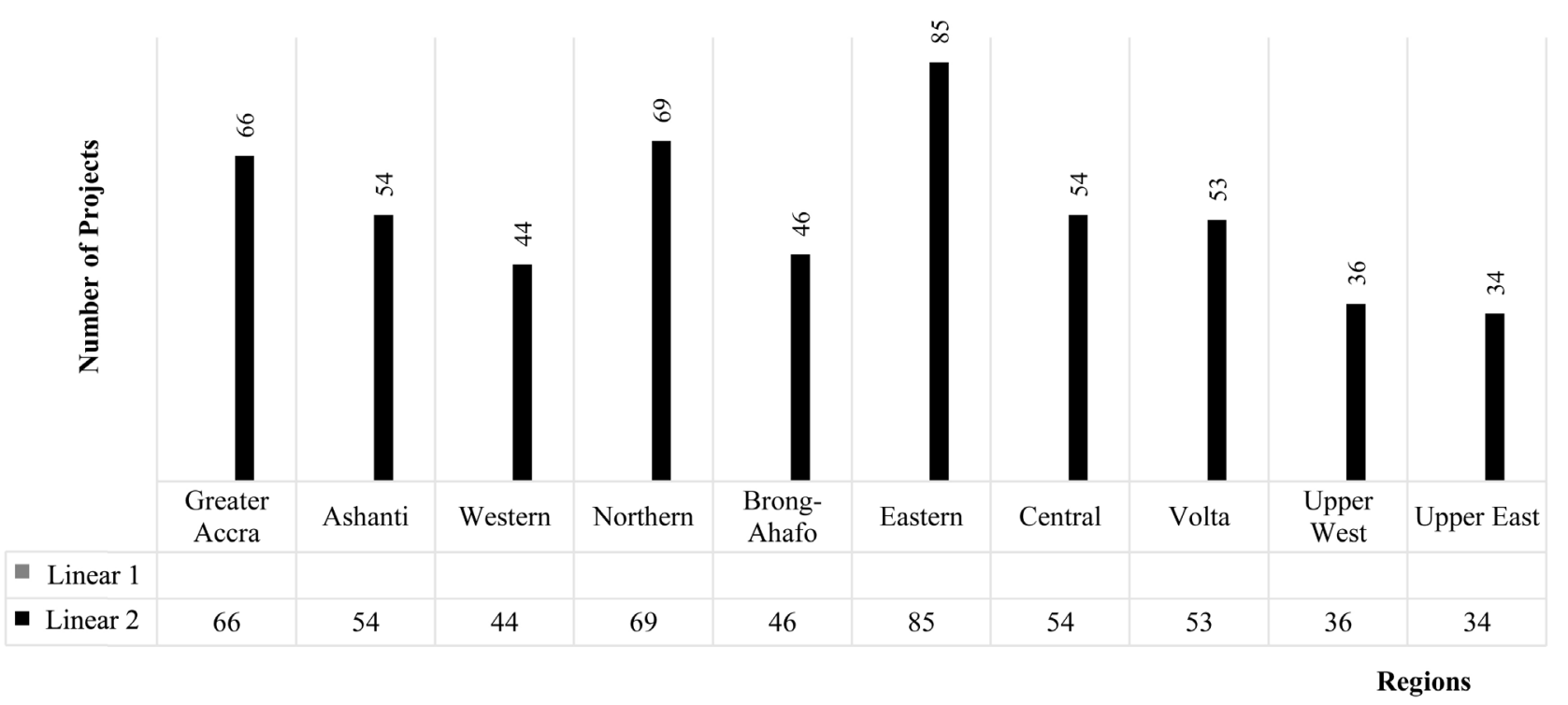

Figure 3. Regional BOQs. 
300

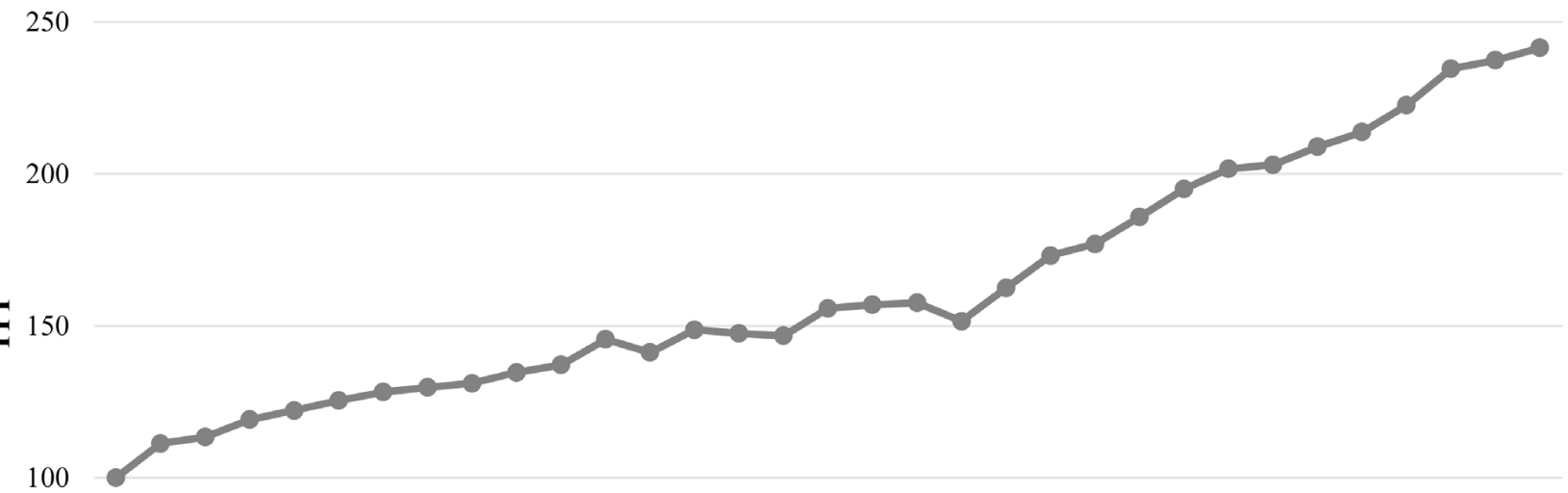

50

0

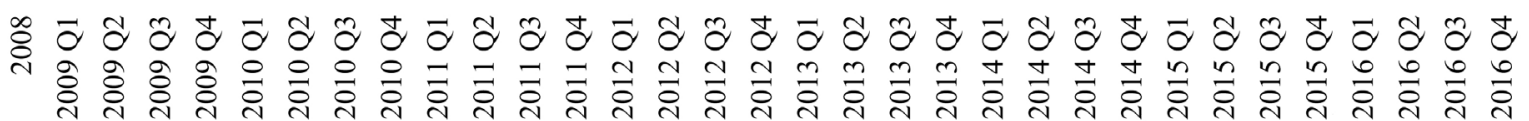

Year(quarterly)

Figure 4. Calculated TPI from 2008-2016.

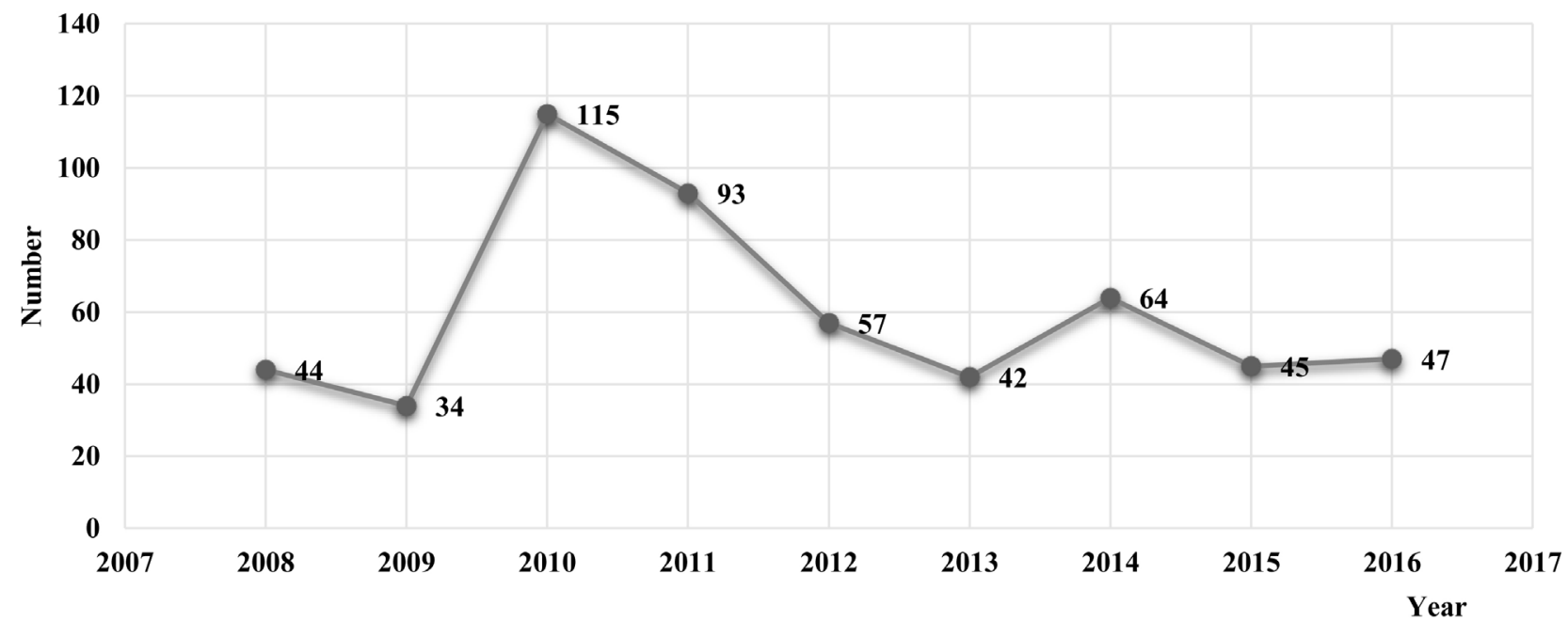

Figure 5. BOQs base on year.

projects to ensure some are completed for such projects to be inaugurated to facilitate votes. This trend affirms the general norm of the Ghanaian building industry in terms of public infrastructures due to the extent that political behavioural thoughts and sensitivities supersede detailed preparation and planning of build- 
ing projects. Building projects in Ghana are often rushed without sufficient budgetary allocation and proper assessment of the needs of society. Upon further analysis including the checking of the various rates in Bills of Quantities in comparison to based rates of CSRI-BRRI, some documents were discarded. In addition, some BOQs with similar descriptions and without dates were also not included in the analysis hence Table 1 presents BOQs which were used for the analysis.

Following this, the BOQs were further grouped quarterly based on the calendar year per month which resulted in 32 quarters covering 2008 to 2016. It is also worth noting that from the analysis of the BOQs, the contract sum ranges from Seventy-Four Thousand, Six Hundred Ninety-Nine Ghana Cedis and Twenty-Four Pesewas (GH\$ 74,699.24) to Eight Million, Six Hundred and Fifty-Nine Thousand, One Hundred and Thirty-One Ghana Cedis and Seventy-Seven Pesewas (GH\$ 8,659,131.77).

\subsection{Making Adjustments}

Adjustments were made by omitting allowance for contingencies, Provisional and Primes cost sum, external works, and VAT + NHIL. Contingencies differ from project to project and cannot be determined accurately during the preparation of the BOQs. Moreover, external works were omitted due to the fact the extent of it cannot be exactly determined during preparation of BOQs. [32] indicated that external works were functions of the nature of the site and not the building. In addition, some items found in external works were normal items that might already have been measured in their original trade sections such as excavations, concrete work, and brickwork among others. VAT + NHIL were also omitted as they get added to the sub-total for all the works, thus it will make it more difficult in the calculation of the index (see Section 2.1.5). Additionally, adjustment was also made for preliminary amounts pro-rata. Furthermore, provisional and prime cost sums were excluded as already discussed in Sections 2.1.3 and 2.1.4.

Table 1. Number of projects used per year.

\begin{tabular}{lc}
\hline Year & Number of projects \\
\hline 2008 & 42 \\
2009 & 29 \\
2010 & 55 \\
2011 & 54 \\
2012 & 40 \\
2013 & 41 \\
2014 & 32 \\
2015 & 34 \\
2016 & 30 \\
Total & 357 \\
\hline
\end{tabular}




\subsection{Detailed Examination of Trades Section for Weighting}

Careful and detailed examination of each trade section is important since each item in the BOQs has some levels of weighting in terms of determining the final contract sum. [46] posited that the key items with the largest price extension in each trade of the bills of quantities should be included in the index. Similarly, [37] suggested that the weights allocated to various items reveal their relative importance and should carefully be chosen to avoid biased and misleading results. Therefore, the nature of the basket remains vital in the development of indices, which are the implications of each item selected need to be examined in detail to establish their influence on the final output. Hence, the following processes were followed:

\section{Weighting}

The weight for the various trade sections was calculated based on the principle of the Consumer Price Index. The Consumer Price Index (CPI) measures changes in the average retail price of a fixed basket of goods and services over time which is taken as a representation of the consumption habits of households [6]. Thus, there was the need to establish a base year for which a weighting can be applied for the preceding years. In this study, the base year was 2008 (see Section 2.2), hence, 42 BOQs were collected including all the various projects as discussed. These 42 projects ranged from January to December. BOQs were further broken down into various work-trade sections. From the analysis, it was evident that not all the trade sections were always present in projects as is indicated in the Standard Method of Measurement (SMM 5, 6 and 7) used in the Ghanaian building industry.

From previous studies, [10] posited that BCIS considered the following sections: excavation and earthworks; in-situ concrete and sundries; membranes; reinforcement; formwork; precast concrete; brickwork; block work; asphalt; slate and tile roofing; sheet metal roofing and flashings; decking; corrugated and troughed roofing; felt roofing; woodwork carcassing; woodwork 1st and 2nd fixings and composite items; insulation; structural steelwork; metal windows; metalwork other than windows; plumbing; wet finishes; dry finishes; glazing; painting and decorating; drainage; roads and paving. [20] suggested the following trade sections in South Africa: earthworks, concrete, formwork and reinforcement, masonry, waterproofing, roof coverings, carpentry and joinery, ceilings, partitions and access flooring, floor coverings, wall linings, and so on, ironmongery, structural steelwork, metalwork, plastering, tiling, plumbing and drainage, glazing, paintwork, provisional sums. In Ghana, [47] in developing cost indices considered the following trade sections based on the democratic approach: preliminaries, site clearing, earthworks, filling and compacting, concrete works, blockwork or brickwork, woodwork, metalwork, plumbing works, sanitary fittings. [39] postulated that the selection of an item to be included in the index is difficult as the results of possible items selected can have effects on the quality of indices. From a literature point of view, there are two main ways of 
selecting items that are the plutocratic and democratic method [48]. The plutocratic approach considers household sharing items of budgetary dealing with the wealthiest constituent, while the democratic approach looks at the average of each household item that contributed to the final account of the index.

In this study, the democratic method was adopted since the arrangement of BOQs enables items to be computed and those occurring frequently and consistently can be assigned weighting. Likewise, the basket for the calculation of the index was based on fixed weight by use of the shortlisted method of indicator items of priced BOQs, which is the predominant and most preferred approach of procurement in Ghana. From the analysis of the $42 \mathrm{BOQs}$, it was realized that the following trade sections were predominant on average and hence, it was considered suitable for the study (Table 2).

Subsequently, further analysis was made by collating the various costs of each trade section and applying the preliminaries through the pro-rata strategies to ensure that each trade section has a proportional level of increase. On this basis, an average of each trade section was calculated which was expressed in percentage. This approach was adopted because it reflected the monetary value in each project, giving a clear contribution to each section. From the analysis, reinforcement recorded the highest level of a weighting of $19.84 \%$ of the total value of Ghष 4,080,525.94 with an average cost of Gh\$ 97,155.38. On the other hand, glazing recorded the lowest level of a weighting of $1.11 \%$ of the cost value of Ghष $228,381.82$ with an average value of Gh\$ 5437.66.

Furthermore, it was evident from the analysis that not all the trade sections were always present, for instance, all projects have earthwork, plain In-Situ concrete, reinforced In-Situ concrete, reinforcement, formwork, masonry, plastered/rendered/roughcast coatings, painting/clear finishing, structural/carcasing

Table 2. Selected trade sections.

\begin{tabular}{cc}
\hline Item & Trade Sections \\
\hline 1 & Preliminaries \\
2 & Earthwork \\
3 & In-Situ Concrete \\
4 & Reinforcement \\
5 & Formwork \\
6 & Masonry \\
7 & Plastered/Rendered/Roughcast Coatings \\
8 & Painting/Clear Finishing \\
9 & Joinery \\
10 & Structural/Carcasing Metal/Timber Carpentry/Timber Framing/First Fixing \\
11 & Metalwork \\
12 & Cladding/Covering/Aluminium Strip Sheet Coverings \\
13 & Glazing \\
\hline
\end{tabular}


metal/timber, carpentry/timber framing/first fixing, and cladding/covering. However, for project 25 joinerys was not present; in project 29, metalwork and glazing were not present while in project 32 glazing was also not present. This may be because of the type of design that was based on the function and purpose of the projects.

In addition, the standard deviation for each trade section was calculated to establish how much the trade sections deviate from the mean. [39] emphasised that standard deviation measures the variation from the mean. From the analysis, the standard deviation ranged from 2.30 to 4.89 which indicates that the values are spread within an acceptable range due to a large representation of each trade section. Table 3 shows the distribution of weighting for each trade section and was expressed in percentage.

Detailed analysis of the trade section

This section concentrated on the detailed analysis of all the trade sections of the 42 projects that are collected for the base year. According to [49] and [50], there is the need to find out the number of indicator items that minimally represent a high portion of the value of building projects. Following this, items of each trade section were short-listed using the BCIS rule. Thus, first items which are more than $1 \%$ of the total project cost are first considered and then they are continued in descending order of value until $25 \%$ of the cost of a trade is reached. In further studies conducted by [20], considered items with a monetary value of more than $5 \%$ of the total value of a particular trade section. However, [20] posited that $5 \%$ was chosen arbitrarily because the literature is vague on it. But he was quick to add that this percentage was deemed acceptable and it found out that the selected item amounted to $24.7 \%$ which represented $75.6 \%$ of the

Table 3. Weight of each trade section.

\begin{tabular}{ccc}
\hline Items & Trade Sections & $\%$ (Trade) \\
\hline 1 & Earthworks & 3.51 \\
2 & In-Situ Concrete & 18.55 \\
3 & Reinforcement for In-Situ Concrete & 19.85 \\
$\mathbf{4}$ & Formwork for In-Situ Concrete & 5.12 \\
$\mathbf{5}$ & Masonry & 8.02 \\
6 & Plastered/Rendered/Roughcast Coatings & 14.01 \\
7 & Painting/Clear Finishing & 6.91 \\
8 & Joinery & 8.02 \\
9 & Structural/Carcasing Metal/Timber/Carpentry/ & 3.80 \\
10 & Timber Framing/First Fixing & 4.38 \\
11 & Metalwork & 6.72 \\
12 & Cladding/Covering/Aluminum Strip Sheet Coverings & 1.11 \\
& Glazing: obscure Sheet Glass & 100.00 \\
\hline
\end{tabular}


total adjusted contract sums. This, however, was equivalent to the BCIS index, where $25 \%$ of the items were considered to be suitable. Hence, as already stated the study follows similar assumptions that were made by BCIS in using the $25 \%$ rule based on each trade section (Table 4).

\section{Identifying the indicator items}

In this section, Excel spreadsheets were used in determining the various items. The items were analysed in terms of the frequencies of occurrence and the weights they represented. It included the adjustments made for preliminary trades. It must be noted that some trade sections consist of several items more than the others hence, priority was given to such trade sections in terms of their occurrence and contributions to the total cost. For example, the reinforcement of the total number of items under the section was:

- $10 \mathrm{~mm}$ diameter bar (3);

- $12 \mathrm{~mm}$ diameter bar (30);

- $16 \mathrm{~mm}$ diameter bar (28)

- $20 \mathrm{~mm}$ diameter bar (20);

- $25 \mathrm{~mm}$ diameter bar (4); and

- Steel fabricated BRC mesh No 65 in floor bed (3).

The most frequent items that occurred were:

- $12 \mathrm{~mm}$ diameter bar (30);

- $16 \mathrm{~mm}$ diameter bar (28); and

- $20 \mathrm{~mm}$ diameter bar (20).

The selected items under the trade section would now include the following and their weight distribution:

- $12 \mathrm{~mm}$ diameter bar, 7.63.

- $16 \mathrm{~mm}$ diameter bar, 7.13.

- $20 \mathrm{~mm}$ diameter bar, 5.09 .

- Total, 19.85.

Application of weighting per items

Final weighting per individual items was applied to the selected indicator items per each trade section. These items were used as a base template for the facilitation of the index calculation through the analysis of the various unit rates per quarter. At this stage, all the BOQs were evaluated using Excel spreadsheet. This involves the critical analysis of each BOQ of each project and the listing of the various items that were selected as indicator items to make up for the weighting as already has been mentioned above. It was shown from the analysis that, some BOQs have more items extracted than others. This was because some BOQs do not have all the items present, and as a result, substitute items were used. For example, formwork sizes and thickness of slabs were of varying sizes. Furthermore, the amounts of preliminaries were added proportionally to the various rates per project. As the process concludes another spreadsheet was developed to contain the only indicator items which match or were closest to the original. In Table 5, 23 indicator items were recorded as literature is vague about 
Table 4. Extract from BOQ, using the 25\% rule.

\begin{tabular}{|c|c|c|c|c|c|}
\hline Item & Description & Qty & Unit & Rate (GHథ) & Total (GH\$) \\
\hline \multirow[t]{2}{*}{1} & Earthworks & & & & \\
\hline & $\begin{array}{l}\text { Filling in layers not exceeding } 225 \mathrm{~mm} \\
\text { thick in making up levels under floors }\end{array}$ & 540 & $\mathrm{~m}^{3}$ & 32.00 & $17,280.00$ \\
\hline \multirow[t]{7}{*}{2} & Concrete Work & & & & \\
\hline & $\begin{array}{l}\text { Plain in-situ concrete (1:3:6 - } 40 \mathrm{~mm} \text { aggregate) } \\
\text { as described in foundation trenches }\end{array}$ & 60 & $\mathrm{~m}^{3}$ & 350.00 & $21,000.00$ \\
\hline & Ditto in $150 \mathrm{~mm}$ floor bedspread and levelled & 810 & $\mathrm{~m}^{2}$ & 52.00 & $42,120.00$ \\
\hline & $\begin{array}{c}\text { Reinforced in-situ vibrated concrete } \\
\text { (1:2:4 - } 20 \mathrm{~mm} \text { aggregate) as described filled } \\
\text { into formwork and around reinforcement } \\
\text { (both measured separately) }\end{array}$ & & & & \\
\hline & Horizontal beam/Columns & 11 & $\mathrm{~m}^{3}$ & 370.00 & 4070.00 \\
\hline & Column & 5 & $\mathrm{~m}^{3}$ & 370.00 & 1850.00 \\
\hline & Supply and fix as described the following & & & & \\
\hline \multirow[t]{3}{*}{3} & $\begin{array}{l}\text { mild steel round bar reinforcement with } \\
\text { and including all necessary binding wires: }\end{array}$ & & & & - \\
\hline & 12 Diameter bars in column base & 2500 & $\mathrm{Kg}$ & 3.40 & 8500.00 \\
\hline & $16 \mathrm{~mm}$ Diameter bars in column & 4440 & $\mathrm{Kg}$ & 3.40 & $15,096.00$ \\
\hline \multirow[t]{2}{*}{4} & Sawn formwork as described to: & & & & \\
\hline & The vertical side of the column & 316 & $\mathrm{~m}^{2}$ & 15.00 & 4740.00 \\
\hline \multirow[t]{2}{*}{5} & Blockwork & & & & \\
\hline & $\begin{array}{l}150 \mathrm{~mm} \text { Solid sandcrete block work in cement } \\
\text { mortar (1:4) as described }\end{array}$ & 1499 & $\mathrm{~m}^{2}$ & 40.00 & $59,960.00$ \\
\hline \multirow[t]{3}{*}{6} & Plastered/Rendered/Roughcast Coatings & & & & \\
\hline & $20 \mathrm{~mm}$ Cement and sand render to the wall & 210 & $\mathrm{~m}^{2}$ & 8.00 & 1680.00 \\
\hline & $10 \mathrm{~mm}$ thick floor tiling, Ceramic Wall Tiling & 810 & $\mathrm{~m}$ & 45.00 & $36,450.00$ \\
\hline \multirow[t]{7}{*}{7} & Painting/Clear Finishing & & & & \\
\hline & $\begin{array}{l}\text { Prepare and apply three coats of emulsion } \\
\text { paint on rendered wall }\end{array}$ & 210 & $\mathrm{~m}^{2}$ & 7.60 & 1596.00 \\
\hline & Prepare and apply three coats of approved & & & & \\
\hline & Coral emulsion paint on: - & & & & \\
\hline & Internal and External walls & 1405 & $\mathrm{~m}^{2}$ & 4.20 & 5901.00 \\
\hline & $\begin{array}{l}\text { Plastic T \& G Ceiling including all } \\
\text { necessary accessories as described }\end{array}$ & & & & \\
\hline & Ceiling lining nailed to the soffit of hardwood & 810 & $\mathrm{~m}^{2}$ & 30.00 & $24,300.00$ \\
\hline \multirow[t]{4}{*}{8} & Joinery & & & & \\
\hline & Wrought hardwood as described & & & & \\
\hline & $\begin{array}{l}44 \mathrm{~mm} \text { (Finished) Panelled door size } \\
\quad 900 \times 2100 \mathrm{~mm} \text { high }\end{array}$ & 42 & No & 230.00 & 9660.00 \\
\hline & $50 \mathrm{~mm} \times 150 \mathrm{~mm}$ Frame plugged & 600 & $\mathrm{~m}$ & 18.00 & $10,800.00$ \\
\hline
\end{tabular}




\section{Continued}

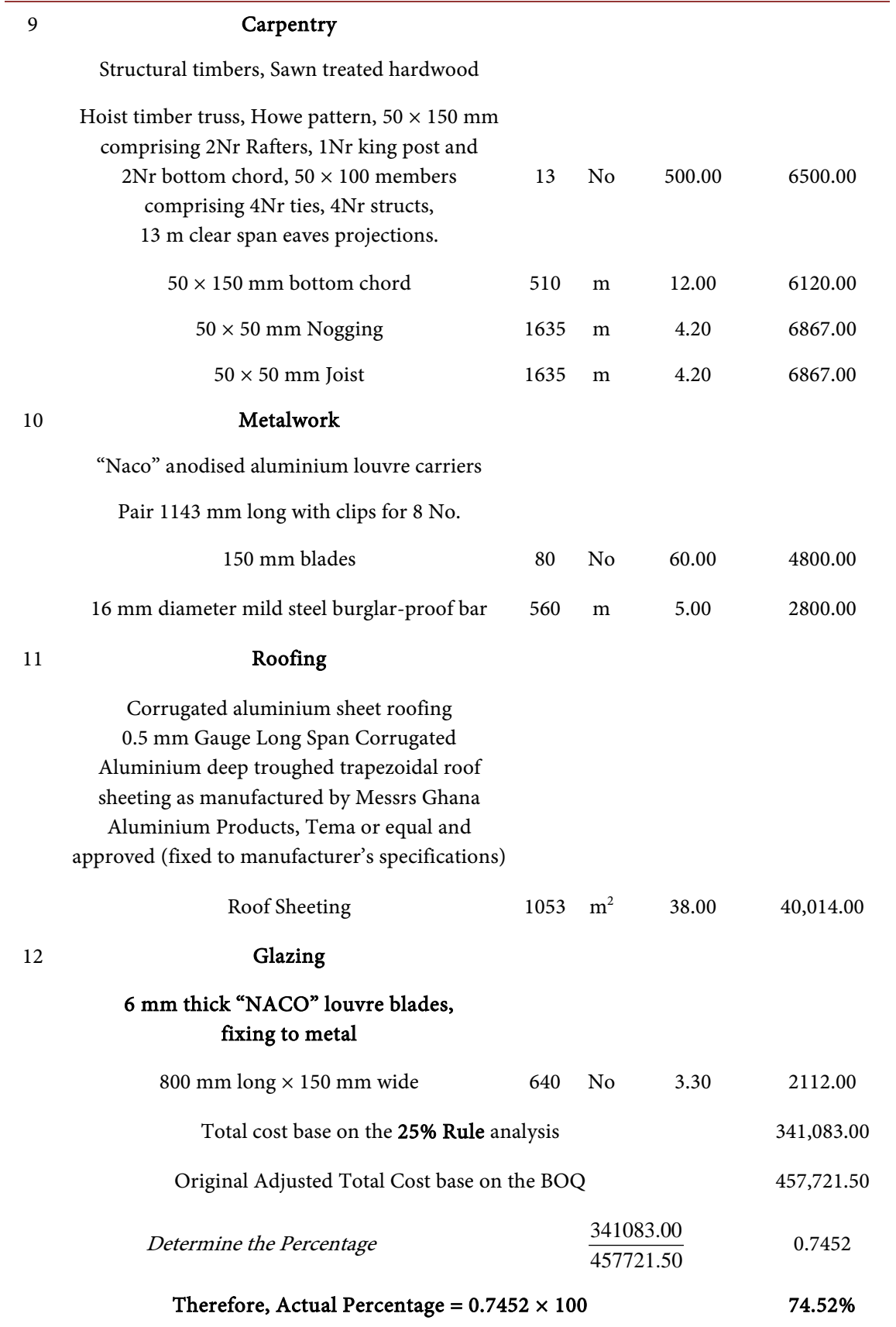

Table 5. Weight of each trade section.

\begin{tabular}{|c|c|c|c|}
\hline Items & Trade Sections & $\begin{array}{c}\% \\
(\text { Items })\end{array}$ & $\begin{array}{c}\% \\
\text { (Trade) }\end{array}$ \\
\hline & Earthworks & & 3.51 \\
\hline 1 & Trenches width exceeding $300 \mathrm{~mm}$; depth not exceeding $2.00 \mathrm{~m}$ & 1.80 & \\
\hline 2 & $\begin{array}{l}\text { Filling to make up levels with imported laterite deposited } \\
\text { in layers } 225 \mathrm{~mm} \text { maximum thick and compacted }\end{array}$ & 1.71 & \\
\hline & In-Situ Concrete & & 18.55 \\
\hline
\end{tabular}




\section{Continued}

oundations poured on or against earth or unblinded hardcore

Reinforced vibrated in-situ concrete

1:2:4 - $20 \mathrm{~mm}$ Aggregate) or $30 \mathrm{~N} / \mathrm{mm}^{2}-20 \mathrm{~mm}$ Aggregate in

Columns/lintel/beam/slab

Reinforcement

5

8

$$
\begin{aligned}
& 12 \mathrm{~mm} \text { diameter bars } \\
& 16 \mathrm{~mm} \text { diameter bars }
\end{aligned}
$$$$
20 \mathrm{~mm} \text { diameter bars }
$$

Formwork for In-Situ Concrete

Sawn formwork to vertical side of columns

$$
\text { Masonry }
$$

Solid blockwork; Sandcrete blocks in cement and/sand (1:6) mortar

$$
150 \mathrm{~mm} \text { thick }
$$$$
125 \mathrm{~mm} \text { thick }
$$

Plastered/Rendered/Roughcast Coatings

$13 \mathrm{~mm}$ thick Cement/Sand (1:6) plaster steel trowelled smooth in.

$$
\text { Walls; width exceeding } 300 \mathrm{~mm} ; 13 \mathrm{~mm} \text { to blockwork }
$$

\section{Stone/Concrete/Quarry/Ceramic Tilling/Mosaic}

$400 \times 400 \mathrm{~mm}$ Ceramic/porcelain tiles

Painting/Clear Finishing

Two undercoats and one finishing coat of "Coral" or equally approved local Emulsion Paint on

$$
\text { Rendered walls; girth; exceeding } 300 \text { mm }
$$

Joinery

$50 \times 150 \mathrm{~mm}$ hardwood frame plugged to concrete work or blockwork including $38 \mathrm{~mm} \times 13 \mathrm{~mm}$ sawn hardwood grounds Hardwood framed panel door $800 \times 2050 \times 44 \mathrm{~mm}$ (finished) 2 leaf in solid hardwood Redwood (D2)

Structural/Carcasing Metal/Timber/Carpentry/Timber Framing/First Fixing

sawn treated hardwood

$$
50 \times 100 \mathrm{~mm} \text { purlins }
$$

$50 \times 150 \mathrm{~mm}$ ceiling joist and noggings

Metalwork

$19 \mathrm{~mm}$ diameter mild steel bar threaded through window
Ditto $40 \mathrm{~mm}$ thick screeded backing bed (1:6) in cement and sand frames as burglar proofing including boring of frame 


\section{Continued}

20

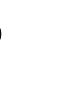

Pair louvre carriers $1125 \mathrm{~mm}$ long with clips for

8 no. $150 \mathrm{~mm}$ blades with dual control

$0.6 \mathrm{~mm}$ corrugated aluminum roofing sheets laid with two and

21 a half corrugations side laps and $150 \mathrm{~mm}$ end laps and fixed to hardwood purlins (measured separately) with approved screws and washers to match

$0.35 \mathrm{~mm}$ corrugated aluminum roofing sheets laid with two and a half corrugations side laps and $150 \mathrm{~mm}$ end laps and fixed to hardwood purlins (measured separately) with approved screws and washers to match

Glazing: obscure Sheet Glass

how many items are suitable for an index. Although, items with higher monetary values were included.

\section{Variation in rate}

Rates for each item varied from one project to another, as such there were different rates that call for critical analysis and examination. Therefore, in order to get a good index, there was the need to use rather an average unit rate of the sample BOQs within a particular time frame. Although unit rates may vary significantly among projects, it may affect the average output unit rates of the indices. In dealing with such issues in the current study median, average, upper and lower limits techniques were adopted to get an appropriate unit rate within each quarter. Furthermore, rate validation was carried out, on this base rate with a variation of \pm 5 to the original rate from Council of Scientific and Industrial Research-Building and Road Research Institution (CSRI-BRRI) were considered for the analysis.

\section{Calculation of index}

The calculation of the index started with establishing the base rate total cost by determining the average of all the four-quarters rates of the 2008 projects. This was done by applying both preliminaries and the weighting to the indicator items rate. From the analysis of 357 projects, preliminaries range from $0.11 \%$ to $39.32 \%$, but quarterly on the average, it ranges from $0.88 \%$ to $10.09 \%$. Its application was therefore done by considering the following postulation. Thus, in South Africa, BER made an allowance of 5\% per project ([20] [51]). However, according to [32] and [49], there are two main approaches in applying preliminaries. These are first applying them as a percentage of all the items rates in the BOQs whiles the second method is to treat them as a separate trade with their own weights. In addition, [40] indicated that BCIS applied their preliminaries as a percentage in addition to the item BOQs. Albeit, it is worth noting that all contractors will not apply the same preliminaries, hence, preliminaries were ap- 
plied by allowing a percentage using the average on the quarterly basis for each unit rate (Table 6).

Following this, weighting for each indicator item was applied as represents in Table 7.

The next step now was to formally calculate the index for each quarter (that is 32 quarters in all) using Laspeyres formulae that were used in conjunction with Excel spreadsheet for the actual index). Laspeyres price index was chosen because it takes into consideration the ratio of the total cost of purchasing a specified set of commodities (basket of goods) at current prices. It does not understate inflation within a particular year. More importantly, it needs less information as compared to other indices ([43]). But it is important to note not all analysis can be presented, hence, only quarter one and two of 2009 in Table 8 was shown here indicating how the indices were calculated (Figure 1 and Figure 2). In addition, Table 9 and Figure 4 showed the other calculated TPI.

Following this, the calculation was made:

Quarter One of 2009, Index $=\frac{50293.37}{45189.21} \times 100=111.30$

Quarter Two of 2009, Index $=\frac{51244.05}{45189.21} \times 100=113.41$

\section{Discussion}

From, Table 9 and Figure 4, it became evident that there were some levels of fluctuation within the prices from one-quarter to the other., For instance, quarter two of 2016 recorded the highest increase in prices changes of $12.02 \%$ followed by quarter one of 2009 with $11.30 \%$. The high level of percentage for quarter two of 2016 was due to a high-rise in exchange rate and interest rate [42]. It must be noted that at this point in time the Ghanaian economy experienced a rough economic situation where some economic indicators were high, thus a direct effect on the construction industry. The quarter two of 2016 showed a rapid increase in price of the construction materials such as cement. In addition, quarter one of 2009 experienced a high rise in price due to the based year syndrome, as the base year considered whole year base rate. Its effects on one-quarter would be severe. This phenomenon is generally with indices as the initial stage increases before stability. On the other hand, quarter three of 2013 recorded least percentage in price with a negative percentage of $-6.04 \%$ followed by quarter four of 2011 of $-4.33 \%$. Although, quarter three of 2013 recorded a stable interest rate and exchange rate, however, there was high percentage increase in producer price index. In addition, quarter four of 2011 recorded fall in interest rate hence, its effects on the indices [42]. From the analysis, it could be deduced that on average there is a change in price of about 4.42 per cent within the eight-year period.

\subsection{Validation of Index}

The process of validation helped in assessing the robustness, usability, and 
Table 6. Application of the preliminaries.

\begin{tabular}{|c|c|c|c|c|}
\hline & Description & Rate & Preliminaries & Total \\
\hline \multicolumn{5}{|c|}{ Earthworks } \\
\hline 1 & $\begin{array}{l}\text { Trenches width exceeding } 300 \mathrm{~mm} \text {; } \\
\text { depth not exceeding } 2.00 \mathrm{~m}\end{array}$ & 5.52 & 1.07 & 5.90 \\
\hline 2 & $\begin{array}{l}\text { Filling to make up levels with imported } \\
\text { laterite deposited in layers } 225 \mathrm{~mm} \\
\text { maximum thick and compacted }\end{array}$ & 15.6 & 1.07 & 16.69 \\
\hline \multicolumn{5}{|c|}{ In-Situ Concrete } \\
\hline \multirow[t]{2}{*}{3} & $\begin{array}{l}\text { Plain in-situ concrete (1:3:6 - } 40 \mathrm{~mm} \text { Aggregate) } \\
\text { or } 20 \mathrm{~N} / \mathrm{mm}^{2}-40 \mathrm{~mm} \text { Aggregate in: - }\end{array}$ & & & \\
\hline & $\begin{array}{l}\text { Foundations poured on or against earth } \\
\text { or unblinded hardcore }\end{array}$ & 128.21 & 1.07 & 137.18 \\
\hline \multirow[t]{3}{*}{4} & $\begin{array}{c}\text { Reinforced vibrated in-situ concrete } \\
\text { (1:2:4 - } 20 \mathrm{~mm} \text { Aggregate) or } \\
30 \mathrm{~N} / \mathrm{mm}^{2}-20 \mathrm{~mm} \text { Aggregate in }\end{array}$ & & & \\
\hline & Columns/lintel/beam/slab & 160.7 & 1.07 & 171.95 \\
\hline & \multicolumn{4}{|l|}{ Reinforcement } \\
\hline 5 & $12 \mathrm{~mm}$ diameter bars & 1957 & 1.07 & 2093.99 \\
\hline 6 & $16 \mathrm{~mm}$ diameter bars & 1945 & 1.07 & 2081.15 \\
\hline \multirow[t]{2}{*}{7} & $20 \mathrm{~mm}$ diameter bars & 1903 & 1.07 & 2036.21 \\
\hline & Formwork for In-Situ Concrete & & & \\
\hline \multirow[t]{3}{*}{8} & Sawn formwork to vertical side of columns & 10.1 & 1.07 & 10.81 \\
\hline & Masonry & & & \\
\hline & $\begin{array}{l}\text { Solid blockwork; sandcrete blocks in } \\
\text { cement and/sand (1:6) mortar }\end{array}$ & & & \\
\hline 9 & $150 \mathrm{~mm}$ thick & 13.95 & 1.07 & 14.92 \\
\hline \multirow[t]{3}{*}{10} & $125 \mathrm{~mm}$ thick & 13.16 & 1.07 & 14.08 \\
\hline & Plastered/Rendered/Roughcast Coatings & & & \\
\hline & $\begin{array}{l}13 \mathrm{~mm} \text { thick Cement/Sand }(1: 4) \\
\text { plaster steel trowelled smooth in. }\end{array}$ & & & \\
\hline 11 & Walls; width exceeding $300 \mathrm{~mm}$ to blockwork & 4.68 & 1.07 & 5.01 \\
\hline \multirow[t]{2}{*}{12} & $\begin{array}{l}\text { Ditto } 40 \mathrm{~mm} \text { thick screeded backing bed } \\
(1: 4) \text { in cement and sand }\end{array}$ & 8.54 & 1.07 & 9.14 \\
\hline & Stone/Concrete/Quarry/Ceramic Tilling/Mosaic & & & \\
\hline \multirow[t]{3}{*}{13} & $400 \times 400 \mathrm{~mm}$ Ceramic/porcelain Tiles & 20.24 & 1.07 & 21.66 \\
\hline & Painting/Clear Finishing & & & \\
\hline & $\begin{array}{l}\text { Two undercoats and one finishing coat of "Coral" } \\
\text { or equally approved local Emulsion Paint on }\end{array}$ & & & \\
\hline 14 & $\begin{array}{c}\text { Rendered walls; girth; exceeding } 300 \mathrm{~mm} \\
\text { Joinery }\end{array}$ & 2.34 & 1.07 & 2.50 \\
\hline
\end{tabular}




\section{Continued}

\begin{tabular}{|c|c|c|c|c|}
\hline 15 & $\begin{array}{c}50 \times 150 \mathrm{~mm} \text { hardwood frame plugged to concrete } \\
\text { work or blockwork including } \\
38 \mathrm{~mm} \times 13 \mathrm{~mm} \text { sawn hardwood grounds }\end{array}$ & 4.28 & 1.07 & 4.57 \\
\hline \multirow[t]{2}{*}{16} & $\begin{array}{l}\text { Hardwood framed panel door } 800 \times 2050 \times 44 \mathrm{~mm} \\
\text { (finished) } 2 \text { leaf in solid hardwood Redwood (D2) }\end{array}$ & 122.37 & 1.07 & 130.94 \\
\hline & $\begin{array}{c}\text { Structural/Carcasing Metal/Timber/Carpentry/Timber } \\
\text { Framing/First } \\
\text { Fixing } \\
\text { sawn treated hardwood }\end{array}$ & & & \\
\hline 17 & $50 \times 100 \mathrm{~mm}$ purlins & 2.88 & 1.07 & 3.08 \\
\hline 18 & $\begin{array}{c}50 \times 150 \mathrm{~mm} \text { ceiling joist and noggings } \\
\text { Metalwork }\end{array}$ & 1.35 & 1.07 & 1.44 \\
\hline 19 & $\begin{array}{l}19 \mathrm{~mm} \text { diameter mild steel bar threaded } \\
\text { through window frames as burglar } \\
\text { proofing including boring of frame }\end{array}$ & 3.45 & 1.07 & 3.69 \\
\hline \multirow[t]{2}{*}{20} & $\begin{array}{l}\text { Pair louvre carriers } 1125 \mathrm{~mm} \text { long with clips for } \\
8 \text { no. } 150 \mathrm{~mm} \text { blades with dual control }\end{array}$ & 28.6 & 1.07 & 30.60 \\
\hline & Description & & & \\
\hline Items & $\begin{array}{l}\text { Cladding/Covering/Aluminium } \\
\text { Strip Sheet Coverings }\end{array}$ & Rate & Preliminaries & Total \\
\hline 21 & $\begin{array}{l}0.6 \mathrm{~mm} \text { corrugated aluminum roofing sheets laid with } \\
\text { two and a half corrugations side laps and } 150 \mathrm{~mm} \\
\text { end laps and fixed to hardwood purlins (measured } \\
\text { separately) with approved screws and washers to match }\end{array}$ & 21.58 & 1.07 & 23.09 \\
\hline 22 & $\begin{array}{l}0.35 \mathrm{~mm} \text { corrugated aluminum roofing sheets laid with } \\
\text { two and a half corrugations side laps and } 150 \mathrm{~mm} \text { end } \\
\text { laps and fixed to hardwood purlins (measured separately) } \\
\text { with approved screws and washers to match }\end{array}$ & 21.53 & 1.07 & 23.04 \\
\hline & Glazing: obscure Sheet Glass & & & \\
\hline 23 & $\begin{array}{c}6 \mathrm{~mm} \text { thick clear sheet glass louvre blades } 150 \mathrm{~mm} \\
\text { wide and not exceeding } 900 \mathrm{~mm} \text { long fixed } \\
\text { into metal clip of louvre carrier }\end{array}$ & 2.3 & 1.07 & 2.46 \\
\hline
\end{tabular}

Table 7. Application of weighting-base year-2008-100.

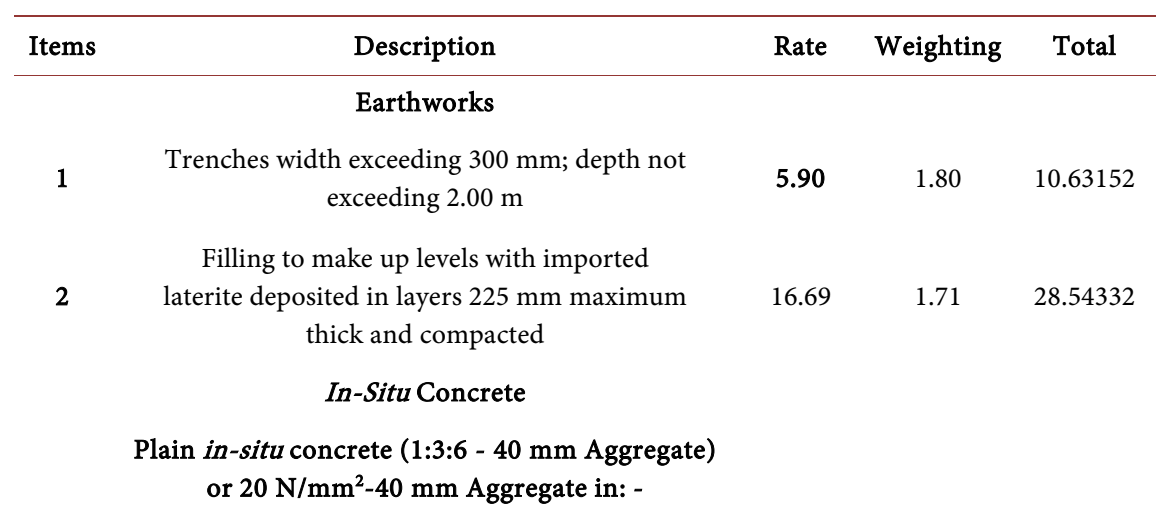




\section{Continued}

3

8

Sawn formwork to vertical side of columns,

\section{Masonry}

Solid blockwork; sandcrete blocks in cement and/sand (1:6) mortar

9

10

12

Stone/Concrete/Quarry/Ceramic Tilling/Mosaic

13

Two undercoats and one finishing coat of "Coral"

$$
\begin{gathered}
400 \times 400 \mathrm{~mm} \text { Ceramic/porcelain Tiles } \\
\text { Painting/Clear Finishing }
\end{gathered}
$$
or equally approved local Emulsion Paint on

$$
150 \mathrm{~mm} \text { thick }
$$

$125 \mathrm{~mm}$ thick

\section{Plastered/Rendered/Roughcast Coatings}

$13 \mathrm{~mm}$ thick Cement/Sand (1:6)

plaster steel trowelled smooth in.

Walls; width exceeding $300 \mathrm{~mm}$; to blockwork

Rendered walls; girth; exceeding 300 mm

\section{Joinery}

$50 \times 150 \mathrm{~mm}$ hardwood frame plugged to concrete work or blockwork including

$38 \mathrm{~mm} \times 13 \mathrm{~mm}$ sawn hardwood grounds

Hardwood framed panel door $800 \times 2050 \times 44 \mathrm{~mm}$

(finished) 2 leaf in solid hardwood Redwood (D2)

Structural/Carcasing

Metal/Timber/Carpentry/Timber Framing/First

\section{Fixing}

\section{sawn treated hardwood}

$\begin{array}{cccc}50 \times 100 \mathrm{~mm} \text { purlins } & 3.08 & 1.65 & 5.08464 \\ 50 \times 150 \mathrm{~mm} \text { ceiling joist and noggings } & 1.44 & 2.15 & 3.105675 \\ \text { Metalwork } & & & \end{array}$

$\begin{array}{lll}137.18 & 5.86 & 803.9023\end{array}$

$\begin{array}{lll}171.95 & 12.69 & 2182.033\end{array}$

$\begin{array}{rrr}2093.99 & 7.63 & 15,977.14 \\ 2081.15 & 7.13 & 14,844.8741 \\ 2036.21 & 5.09 & 10364.31\end{array}$

$10.81 \quad 5.12 \quad 55.33184$

$\begin{array}{lll}14.92 & 6.05 & 90.30533 \\ 14.08 & 1.97 & 27.73996\end{array}$

$\begin{array}{lll}5.01 & 5.25 & 26.2899\end{array}$

$\begin{array}{lll}9.14 & 3.75 & 34.26675\end{array}$

$\begin{array}{lll}21.66 & 5.01 & 108.5006\end{array}$

$\begin{array}{lll}2.5 & 6.91 & 17.30126\end{array}$

$\begin{array}{lll}4.57 & 5.35 & 24.50086\end{array}$

$\begin{array}{lll}130.94 & 2.67 & 349.5989\end{array}$ 


\section{Continued}

\begin{tabular}{|c|c|c|c|c|}
\hline 19 & $\begin{array}{c}19 \mathrm{~mm} \text { diameter mild steel bar threaded through } \\
\text { window frames as burglar proofing including } \\
\text { boring of frame }\end{array}$ & 3.69 & 2.07 & 7.641405 \\
\hline \multirow[t]{4}{*}{20} & $\begin{array}{l}\text { Pair louvre carriers } 1125 \mathrm{~mm} \text { long with clips } \\
\text { for } 8 \text { no. } 150 \mathrm{~mm} \text { blades with dual control }\end{array}$ & 30.6 & 2.31 & 70.69062 \\
\hline & \multicolumn{4}{|l|}{ Cladding/Covering/Aluminium Strip } \\
\hline & \multicolumn{4}{|l|}{ Sheet Coverings } \\
\hline & $\begin{array}{l}0.6 \mathrm{~mm} \text { corrugated aluminum roofing sheets laid } \\
\text { with two and a half corrugations side laps and }\end{array}$ & & & \\
\hline 21 & $\begin{array}{l}150 \mathrm{~mm} \text { end laps and fixed to hardwood purlins } \\
\text { (measured separately) with approved screws } \\
\text { and washers to match }\end{array}$ & 23.09 & 3.26 & 75.27536 \\
\hline & $\begin{array}{l}0.35 \mathrm{~mm} \text { corrugated aluminum roofing sheets } \\
\text { laid with two and a half corrugations side laps and }\end{array}$ & & & \\
\hline \multirow[t]{3}{*}{22} & $\begin{array}{c}150 \mathrm{~mm} \text { end laps and fixed to hardwood } \\
\text { purlins (measured separately) with approved } \\
\text { screws and washers to match }\end{array}$ & 23.04 & 3.46 & 79.70837 \\
\hline & Glazing: obscure Sheet Glass & & & \\
\hline & $6 \mathrm{~mm}$ thick clear sheet glass louvre blades & & & \\
\hline \multirow[t]{2}{*}{23} & $\begin{array}{l}150 \mathrm{~mm} \text { wide and not exceeding } 900 \mathrm{~mm} \text { long } \\
\text { fixed into metal clip of louvre carrier }\end{array}$ & 2.46 & 1.11 & 2.73171 \\
\hline & TOTAL & & 100 & $45,189.21$ \\
\hline
\end{tabular}

practicality of the developed indices. As corroborated by [15] the validation of the indices helped in testing the practical application of the indices and examine how close the estimates produced using the indices do resemble reality. The validation of the indices was therefore performed by comparing the actual cost, current cost and adjusted cost using the indices. These projects were randomly selected and were similar to the type of buildings that were used in the development of the indices. The actual cost represents the original cost at the time of pricing BOQ in quarter two of 2012 (for example original estimated cost for project one was Gh $\$ 255,852.93$ ) while the current cost was generated using the prices of items as 2012Q3 (using the Building and Road Research Institute basic rates: this was used because of its recognition nationally and widely acceptable by industry players) and was estimated at Gh $₫ 273,229.05$. Afterward, the indices were also applied in adjusting the actual cost in 2012Q2 to 2012Q3 which recorded a cost estimate of $\mathrm{Gh} \$ 257,771.83$. In comparing the current cost to the adjusted the cost using the indices, the percentage change in price was negatively indicating reduction in price of $0.75 \%$. This recorded a difference of Gh $\$$ $15,457.22$ beckoning a $94.34 \%$ to the current price with a margin of $5.42 \%$. Using the same scenario fifteen extra projects were priced and adjusted using the indices (Table 10). On a whole, the margin of error in terms of the usage of the indices developed was $\pm 2.69 \%$ which approximates to $\pm 3 \%$. In addition, there was a deviation of $5.32 \%$. This indicates that indices can be used to predict tender price at a relatively low margin. Such prediction error and deviation must be 
Table 8. Calculation of Index: 2009 quarter 1 and quarter 2.

\begin{tabular}{|c|c|c|c|c|c|c|c|}
\hline \multirow{2}{*}{ Items } & \multirow{2}{*}{ Items } & \multicolumn{3}{|c|}{ 2009-Quarter 1} & \multicolumn{3}{|c|}{ 2009-Quarter 2} \\
\hline & & Rate & Weighting & Total & Rate & Weighting & Total \\
\hline & Earthworks & & & & & & \\
\hline 1 & $\begin{array}{l}\text { Trenches width exceeding } 300 \mathrm{~mm} \text {; depth not } \\
\text { exceeding } 2.00 \mathrm{~m}\end{array}$ & 5.07 & 1.80 & 9.12 & 5.75 & 1.8 & 10.35 \\
\hline \multirow[t]{4}{*}{2} & $\begin{array}{l}\text { Filling to make up levels with imported laterite deposited } \\
\text { in layers } 225 \mathrm{~mm} \text { maximum thick and compacted }\end{array}$ & 15.71 & 1.71 & 26.87 & 17.17 & 1.71 & 29.35 \\
\hline & In-Situ Concrete & & & & & & \\
\hline & Plain in-situ concrete (1:3:6 - $40 \mathrm{~mm}$ Aggregate) & & & & & & \\
\hline & or $20 \mathrm{~N} / \mathrm{mm}^{2}-40 \mathrm{~mm}$ Aggregate in: - & & & & & & \\
\hline \multirow[t]{3}{*}{3} & $\begin{array}{l}\text { Foundations poured on or against earth or } \\
\text { unblinded hardcore }\end{array}$ & 161.14 & 5.86 & 944.27 & 177.55 & 5.86 & 1040.44 \\
\hline & Reinforced vibrated in-situ concrete (1:2:4-20 mm & & & & & & \\
\hline & Aggregate) or $30 \mathrm{~N} / \mathrm{mm}^{2}-20 \mathrm{~mm}$ Aggregate in & & & & & & \\
\hline \multirow[t]{2}{*}{4} & Columns/lintel/beam/slab & 173.32 & 12.69 & 2199.38 & 228.28 & 12.69 & 2896.86 \\
\hline & Reinforcement & & & & & & \\
\hline 5 & $12 \mathrm{~mm}$ diameter bars & 2287.12 & 7.63 & $17,450.73$ & 2313.22 & 7.63 & $17,649.89$ \\
\hline 6 & $16 \mathrm{~mm}$ diameter bars & 2279.69 & 7.13 & $16,4254.22$ & 2267.57 & 7.13 & $16,167.75$ \\
\hline \multirow[t]{2}{*}{7} & $20 \mathrm{~mm}$ diameter bars & 2404.08 & 5.09 & $12,236.74$ & 2343.66 & 5.09 & $11,929.23$ \\
\hline & Formwork for In-Situ Concrete & & & & & & \\
\hline \multirow[t]{4}{*}{8} & Sawn formwork to vertical side of columns & 10.11 & 5.12 & 51.74 & 13.62 & 5.12 & 69.74 \\
\hline & Masonry & & & & & & \\
\hline & $\begin{array}{l}\text { Solid blockwork; sandcrete blocks in cement } \\
\text { and/sand (1:6) mortar }\end{array}$ & & & & & & \\
\hline & Walls & & & & & & \\
\hline 9 & $150 \mathrm{~mm}$ thick & 19.12 & 8.02 & 153.36 & 23.59 & 8.02 & 189.18 \\
\hline \multirow[t]{3}{*}{10} & $125 \mathrm{~mm}$ thick & & & & & & \\
\hline & Plastered/Rendered/Roughcast Coatings & & & & & & \\
\hline & $\begin{array}{l}13 \mathrm{~mm} \text { thick Cement/Sand (1:6) plaster steel } \\
\text { trowelled smooth in. }\end{array}$ & & & & & & \\
\hline 11 & Walls; width exceeding $300 \mathrm{~mm}$; to blockwork & 3.85 & 5.25 & 20.19 & 7.34 & 5.25 & 38.51 \\
\hline \multirow[t]{2}{*}{12} & $\begin{array}{l}\text { Ditto } 40 \mathrm{~mm} \text { thick screeded backing bed (1:6) } \\
\text { in cement and sand }\end{array}$ & 16.36 & 3.75 & 61.35 & 17.58 & 3.75 & 65.92 \\
\hline & Stone/Concrete/Quarry/Ceramic Tilling/Mosaic & & & & & & \\
\hline \multirow[t]{3}{*}{13} & $400 \times 400 \mathrm{~mm}$ Ceramic/porcelain Tiles & 25.47 & 5.01 & 127.61 & 31.96 & 5.01 & 160.11 \\
\hline & Painting/Clear Finishing & & & & & & \\
\hline & $\begin{array}{l}\text { Two undercoats and one finishing coat of "Coral" } \\
\text { or equally approved local Emulsion Paint on }\end{array}$ & & & & & & \\
\hline \multirow[t]{2}{*}{14} & Rendered walls; girth; exceeding $300 \mathrm{~mm}$ & 2.96 & 6.91 & 20.47 & 9.83 & 6.91 & 67.89 \\
\hline & Joinery & & & & & & \\
\hline
\end{tabular}




\section{Continued}

Hardwood framed panel door $800 \times 2050 \times 44 \mathrm{~mm}$ (finished) 2 leaf in solid hardwood Redwood (D2) work or blockwork including $38 \mathrm{~mm} \times 13 \mathrm{~mm}$ sawn hardwood grounds

$50 \times 150 \mathrm{~mm}$ hardwood frame plugged to concrete

Structural/Carcasing Metal/Timber/Carpentry/Timber Framing/First Fixing

\section{Sawn treated hardwood}

17

18

19

20

$$
50 \times 100 \mathrm{~mm} \text { purlins }
$$

$50 \times 150 \mathrm{~mm}$ ceiling joist and noggings

\section{Metalwork}

$19 \mathrm{~mm}$ diameter mild steel bar threaded through window frames as burglar proofing including boring of frame

Pair louvre carriers $1125 \mathrm{~mm}$ long with clips for

8 no. $150 \mathrm{~mm}$ blades with dual control

\section{Cladding/Covering/Aluminium Strip Sheet Coverings}

$0.6 \mathrm{~mm}$ corrugated aluminum roofing sheets laid with two and a half corrugations side laps and $150 \mathrm{~mm}$ end laps and fixed to hardwood purlins (measured separately) with approved screws and washers to match

$0.35 \mathrm{~mm}$ corrugated aluminum roofing sheets laid with two and a half corrugations side laps and $150 \mathrm{~mm}$ end laps and fixed to hardwood purlins (measured separately) with approved screws and washers to match

\section{Glazing: obscure Sheet Glass}

$6 \mathrm{~mm}$ thick clear sheet glass louvre blades $150 \mathrm{~mm}$ wide and not exceeding $900 \mathrm{~mm}$ long fixed into metal clip of louvre carrier

5.35

42.55

10.16

5.35

54.37

162.70

2.67

434.40

177.55

2.67

474.06

3.07

5.68

3.33

34.41

2.31

79.49

48.36

2.31

111.72

19.13

Table 9. Calculated TPI from 2008-2016.

\begin{tabular}{ccc}
\hline No & Year & Index \\
\hline Base Year & 2008 & 100 \\
1 & $2009 \mathrm{Q} 1$ & 111.30 \\
2 & $2009 \mathrm{Q} 2$ & 113.41 \\
3 & $2009 \mathrm{Q} 3$ & 119.12 \\
4 & $2009 \mathrm{Q} 4$ & 122.14 \\
5 & $2010 \mathrm{Q} 1$ & 125.37 \\
6 & $2010 \mathrm{Q} 2$ & 128.17 \\
7 & $2010 \mathrm{Q} 3$ & 129.75 \\
9 & $2010 \mathrm{Q} 4$ & 131.05 \\
\hline
\end{tabular}




\section{Continued}

\begin{tabular}{|c|c|c|}
\hline 10 & $2011 \mathrm{Q} 2$ & 137.14 \\
\hline 11 & 2011 Q3 & 145.58 \\
\hline 12 & $2011 \mathrm{Q} 4$ & 141.25 \\
\hline 13 & 2012 Q1 & 148.73 \\
\hline 14 & 2012 Q2 & 147.46 \\
\hline 15 & 2012 Q3 & 146.71 \\
\hline 16 & 2012 Q4 & 155.71 \\
\hline 17 & 2013 Q1 & 156.92 \\
\hline 18 & 2013 Q2 & 157.57 \\
\hline 19 & 2013 Q3 & 151.53 \\
\hline 20 & 2013 Q4 & 162.45 \\
\hline 21 & 2014 Q1 & 173.12 \\
\hline 22 & 2014 Q2 & 176.95 \\
\hline 23 & 2014 Q3 & 185.79 \\
\hline 24 & 2014 Q4 & 194.99 \\
\hline 25 & 2015 Q1 & 201.65 \\
\hline 26 & 2015 Q2 & 202.98 \\
\hline 27 & 2015 Q3 & 208.92 \\
\hline 28 & 2015 Q4 & 213.76 \\
\hline 29 & 2016 Q1 & 222.61 \\
\hline 30 & 2016 Q2 & 234.63 \\
\hline 31 & 2016 Q3 & 237.41 \\
\hline 32 & 2016 Q4 & 241.52 \\
\hline
\end{tabular}

Table 10. Validation of the indices.

\begin{tabular}{|c|c|c|c|c|c|c|c|c|c|c|}
\hline \multirow[b]{2}{*}{ No } & \multirow[b]{2}{*}{ Project } & \multicolumn{2}{|c|}{ Actual Cost } & \multicolumn{2}{|c|}{ Current Cost } & \multicolumn{2}{|c|}{$\begin{array}{c}\text { Adjusted } \\
\text { Cost per Index }\end{array}$} & \multirow{2}{*}{$\begin{array}{c}\text { Difference } \\
(B-D) \\
\text { Ghe }\end{array}$} & \multirow{2}{*}{$\begin{array}{l}\text { Percentage } \\
(E)=(B / D)\end{array}$} & \multirow{2}{*}{$\begin{array}{c}\% \text { of } \\
\text { Margin } \\
(100-E)\end{array}$} \\
\hline & & Quarter & $\begin{array}{c}\text { Total } \\
\text { Cost (A), } \\
\text { Ghe }\end{array}$ & Quarter & $\begin{array}{c}\text { Current } \\
\text { Price (B) } \\
\text { Ghe }\end{array}$ & $\begin{array}{l}\text { Index } \\
\text { (C) }\end{array}$ & $\begin{array}{c}\text { New Cost } \\
\text { Ghe } \\
D=(C \times A)\end{array}$ & & & \\
\hline 1 & 6-Unit-Class-Block & 2012Q2 & $255,852.93$ & 2012Q3 & $273,229.05$ & 1.01 & $258,411.46$ & $14,817.59$ & 94.58 & 5.42 \\
\hline 2 & $\begin{array}{c}3 \text { Story-Administration } \\
\text { Block }\end{array}$ & $2012 \mathrm{Q} 4$ & $1,385,399.40$ & 2013 Q1 & $1,448,691.22$ & 1.02 & $1,413,107.39$ & $35,583.83$ & 97.54 & 2.46 \\
\hline 3 & Library-Block & 2014 Q4 & $663,135.80$ & 2015 Q1 & $675,141.82$ & 1.07 & $707,366.96$ & $-32,225.14$ & 104.77 & -4.77 \\
\hline 4 & 18-Unit-classroom & 2013 Q2 & $826,562.57$ & 2013Q3 & $837,950.79$ & 1.06 & $876,156.32$ & $-38,205.53$ & 104.56 & -4.56 \\
\hline 5 & Library-Block & 2012Q1 & $1,096,065.56$ & 2014 Q2 & $1,163,294.86$ & 1.01 & $1,109,985.59$ & $53,309.27$ & 95.42 & 4.58 \\
\hline 6 & Library-Block & 2016Q1 & $1,360,507.03$ & 2016Q2 & $1,432,168.20$ & 1.12 & $1,524,176.03$ & $-92,007.83$ & 106.42 & -6.42 \\
\hline 7 & Library-Block & 2016Q2 & $1,500,002.98$ & 2016 Q3 & $1,621,150.41$ & 1.03 & $1,541,703.06$ & $79,447.35$ & 95.10 & 4.90 \\
\hline 8 & $\begin{array}{l}\text { Administration-ICT } \\
\text { Block }\end{array}$ & 2014Q1 & $642,626.00$ & 2014 Q2 & $696,097.41$ & 1.04 & $667,110.05$ & $28,987.36$ & 95.84 & 4.16 \\
\hline
\end{tabular}




\section{Continued}

\begin{tabular}{|c|c|c|c|c|c|c|c|c|c|c|}
\hline 9 & Lecture Hall & 2014Q3 & $2,643,012.39$ & 2014 Q4 & $3,177,088.71$ & 1.09 & $2,885,905.23$ & $291,183.48$ & 90.83 & 9.17 \\
\hline 10 & Library-Block & 2014 Q2 & $5,997,049.76$ & 2014 Q3 & $6,159,296.07$ & 1.09 & $6,528,388.37$ & $-369,092.30$ & 105.99 & -5.99 \\
\hline 11 & Library-Block & 2012 Q2 & $530,066.00$ & 2012 Q3 & $586,851.90$ & 1.01 & $535,366.66$ & $51,485.24$ & 91.23 & 8.77 \\
\hline 12 & Science Block & 2012Q3 & $1,659,832.54$ & 2012 Q4 & $1,793,436.41$ & 1.09 & $1,809,217.47$ & $-15,781.06$ & 100.88 & -0.88 \\
\hline 13 & Lecture Hall & 2012Q3 & $1,129,227.79$ & 2012 Q4 & $1,241,815.96$ & 1.09 & $1,230,858.29$ & $10,957.67$ & 99.12 & 0.88 \\
\hline 14 & Administration Block & 2013Q1 & $1,618,688.28$ & 2013 Q2 & $1,749,363.51$ & 1.01 & $1,629,209.75$ & $120,153.76$ & 93.13 & 6.87 \\
\hline 15 & Library-Block & 2013Q2 & $2,383,130.44$ & 2013 Q3 & $2,667,180.65$ & 1.06 & $2,526,118.27$ & $141,062.38$ & 94.71 & 5.29 \\
\hline \multicolumn{10}{|c|}{ Deviation } & 5.32 \\
\hline \multicolumn{10}{|c|}{ Margin of Error } & $\pm 2.69 \approx 3.00$ \\
\hline
\end{tabular}

Source: Researcher's survey, 2017.

considered based on the type of projects and economic condition existing within the timeframe.

\subsection{Practical Application of the Indices}

Assuming a 6-Unit-Class-Block was built in 2012Q2 and the cost was Gh $₫ 255,852.93$. What will be the probable cost in 2015Q3, if the TI index for 2012Q2 is 147.46 and TI for $2015 \mathrm{Q} 3$ is 208.92 ?

Price at 2015Q3 $=\frac{\text { Current index at 2015Q3 }}{\text { Base index at 2012Q2 }} \times$ Cost of building at 2012Q2

$$
\text { Price at } 2015 Q 3=\frac{208.92}{147.46} \times \text { Gh } \not 255852.93
$$

$n=\mathrm{Gh} \phi 319,948.14$.

Note: The prevailing price of the 6-unit class as of in 2015 was around Ghe $3,500,000$ to Ghe 3,600,000. The Gh $319,948.14$ produced by using the index is exclusive of the Prime Cost sum, Provisional Sum and Contingency Sum.

\section{Conclusions}

Pricing of construction resources remains a critical challenge to project stakeholders over decades and even more intense in recent times due to various economic recessions and fluctuation in both developed and developing countries. However, the quest of achieving value for money is hinged on an effective and efficient pricing regime. In Ghana, many project disputes can be attributed to ineffective pricing strategies that are not based on realistic data. Historical data over the years have been perceived by the researchers and practitioners as an effective medium of obtaining a basis for pricing. Notwithstanding, the development of historical data into various indices used in updating cost, cost planning, fluctuation analysis among others in developed countries and areas such as United State of America (USA), Hong Kong (China), Finland and South Africa, 
developing countries such as Ghana is yet to take advantage of such developments. In addition, construction professionals in Ghana are challenged in determining the initial cost of the project due to lack of effective indices for such analysis. This study has shown that an effective and efficient pricing system can be achieved by developing tender price index which will propel such regime. It has therefore suggested policy makers and building industry professionals to take a critical look at pricing building projects due to the wider implications it has on the national economy and development.

Notwithstanding the contribution this study makes to the body of knowledge and practice in the building industry, this study is limited in several ways. For instance, the surveys of the study were limited to practicing Quantity Surveyors in chartered quantity surveying firms, Architectural Service and Engineering Limited, public universities and polytechnics. The secondary data for the analysis for the indices were based on the public non-residential educational institution facilities with a total contract sum of ranging from Seven Four Thousand, Six Hundred Ninety-Nine Ghana Cedis and Twenty-Four Pesewas to Eight Million, Six Hundred and Fifty-Nine Thousand, One Hundred and Thirty-One Ghana Cedis and Seventy-Seven Pesewas (GH\$ 8,659,131.77) and spanning eight years (2008 to 2016). Furthermore, the indices were developed based on accepted contract documents (priced bills of quantities). Furthermore, initial price quotation is used and the reason is that it will take a very long period to organize the final price bills of quantities. The index developed was based on $357 \mathrm{BOQs}$, with an average of $40 \mathrm{BOQs}$ per year with a minimum of seven projects per quarter. Additionally, provisional sum and prime cost sums were excluded in the index development due to the difficulties involved in getting a unit rate to represent the item. In terms of procurement, many of the contract documents were based on the traditional procurement system which remains predominant in the Ghanaian Building Industry. The source of funding for projects (BOQs) for the indices was not considered.

\section{Further Studies}

The current tender price indices considered considers non-residential building of educational institutions, it is therefore recommended that further studies conducted on price indices to include other types of buildings, for example, commercial and residential buildings. In addition, there is no inclusion of Prime Cost and Provisional Sums in current indices; it is hence recommended that further studies in this area should consider their influence in TPI development. Lastly, the current indices considered only previous years due to that a model is being developed to help in predicting the succeeding years.

\section{Conflicts of Interest}

The authors declare no conflicts of interest regarding the publication of this paper. 


\section{References}

[1] Ng, S.T., Cheung, S.O., Skitmore, M. and Wong, T.C. (2004) An Integrated Regression Analysis and Time Series Model for Construction Tender Price Index Forecasting. Construction Management and Economics, 22, 483-493. https://doi.org/10.1080/0144619042000202799

[2] Wong, J.M. and Ng, S.T. (2010) Forecasting Construction Tender Price Index in Hong Kong Using Vector Error Correction Model. Construction Management and Economics, 28, 1255-1268. https://doi.org/10.1080/01446193.2010.487536

[3] Tysoe, B.A. (1981) Construction Cost and Price Indices: Description and Use. E \& FN Spon, London.

[4] Ng, T.S., Cheung, S.O., Martin Skitmore, R., Lam, K.C. and Wong, L.Y. (2000) Prediction of Tender Price Index Directional Changes. Construction Management \& Economics, 18, 843-852. https://doi.org/10.1080/014461900433122

[5] Rowlinson, S.M. and Walker, A. (1994) The Construction Industry in Hong Kong. Longman, London.

[6] Organisation for Economic Co-Operation and Development (1997) Construction Price Indices: Sources and Methods. OECD: Statistical Office of the European Communities, Paris.

[7] Goh, B.H. (2005) The Dynamic Effects of the Asian Financial Crisis on Construction Demand and Tender Price Levels in Singapore. Building and Environment, 40, 267-276. https://doi.org/10.1016/j.buildenv.2004.07.012

[8] Ho, P.H. (2013) Forecasting Tender Price Index under in Complete Information. Journal of the Operational Research Society, 64, 1248-1257. https://doi.org/10.1057/jors.2012.168

[9] Smith, A.J. (1995) Estimating, Tendering and Bidding for Construction: Theory and Practice. Macmillan, Boston. https://doi.org/10.1007/978-1-349-13630-8

[10] Yu, M.K.W. and Ive, G. (2008) The Compilation Methods of Building Price Indices in Britain: A Critical Survey. Construction Management and Economics, 26, 693-705. https://doi.org/10.1080/01446190802043918

[11] O’Donovan, T.M. (1983) Short Term Forecasting: An Introduction to Box-Fenkins Practice. Macmillan, London.

[12] Bowerman, B.L. and O’Connel, R.T. (1987) Time Series Forecasting. Duxbury Press, Boston.

[13] Laryea, S. (2010) Contractor Project Estimates vs. Consultant Project Estimates in Ghana. The Construction, Building and Real Estate Research Conference of the Royal Institution of Chartered Surveyors, Paris, 2-3 September 2010, 1-17.

[14] Ssegawa, J.K. and Motsipa, E. (2003) The Extent of Variability of Rates of Building Items in Botswana. Botswana Journal of Technology, 12, 62-69. https://doi.org/10.4314/bjt.v12i2.15376

[15] Hassanein, A.A. and Khalil, B.N. (2006) Building Egypt 1-a General Indicator Cost Index for the Egyptian Construction Industry. Engineering, Construction and Architectural Management, 13, 463-480. https://doi.org/10.1108/09699980610690747

[16] Robinson, K. (2007) Fighting Inflation, Graduate Degree Based Thesis. The University of Central Missouri, Warrensburg.

[17] Muriithi, N. and Crawford, L. (2003) Approaches to Project Management in Africa: Implications for International Development Projects. International Journal of Project Management, 21, 309-319. https://doi.org/10.1016/S0263-7863(02)00048-0 
[18] Tarek, Z., Emad, E. and Mohammad, A. (2012) A Framework for Performance Assessment of Organizations in the Construction Industry. International Journal of Architecture, Engineering and Construction, 1, 199-212. https://doi.org/10.7492/IJAEC.2012.022

[19] Ashworth, A. (2004) Cost Studies of Buildings. 4th Edition, Prentice Hall, Harlow.

[20] Cruywagen, H. (2014) Towards the Establishment of a Relevant National Tender Price Index for the South African Building Industry. Acta Structilia: Journal for the Physical and Development Sciences, 21, 22-43.

[21] Ghani, A. (2006) The Importance of Preliminaries Items. Master's Degree, University Technology Malaysia, Skudai.

[22] Kilian, W.F. (1980) An Assessment of the BER Building Cost Index. Building Survey No. 44, January 1980. University of Stellenbosch, Stellenbosch.

[23] Ajator, U.O. (2017) Impact of Risk Factors; Prime Cost Sums and Provisional Sums on Project Cost Performance. International Journal of Engineering Inventions, 6, 10-24.

[24] Olusegun, A.E. (2010) Adjustments of Prime Cost and Provisional Sums on Building Project in Nigeria: Causes, Effects and Solutions. Journal of Applied Science Research, 6, 1212-1214.

[25] Seeley, I.H. (1997) Quantity Surveying Practice. Second Edition, Macmillan, London, 240-241. https://doi.org/10.1007/978-1-349-14402-0 8

[26] Project Management Institute (PMI) (2012) A Guide to the Project Management Body of Knowledge. 5th Edition, PMI, Newtown Square.

[27] Xiong, B. and Xia, B. (2014) Examining the Effects of Early Cost Drivers on Contingencies. Construction Research Congress 2014: Construction in a Global Network, Atlanta, 19-21 May 2014, 1518-1527.

https://doi.org/10.1061/9780784413517.155

[28] Asamoah, R.O., Danku, J.C. and Amissah, P.B. (2013) Estimating Contingency Sum for Building Works in Ghana. Science, Technology and Development, 32, 266-275.

[29] Baccarini, D. (2004) Accuracy in Estimating Project Cost Construction Contingency, a Statistical Analysis. Proceedings of the Construction and Building Research Conference of RICS, Leeds, 7-8 September 2004, 7-8.

[30] Awunyo-Vitor, D. (2013) Value Added Tax Administration in the Construction Industry in Ghana. Journal of Finance and Management in Public Services, 14, 107-117.

[31] Sowa, Y. (2010) GhIS Unveils VAT Levy in Construction Industry. News Agency, Ghana. http://www.ghanaweb.com

[32] Van der Walt, P. (1992) N Kontrakprysindeks vir geboue in die Republiek van Suid-Afrika. PhD proefskrif, Universiteit van Pretoria, Pretoria.

[33] Statistics Finland (2001) Building Cost Index 2000 = 100: User's Handbook. Hakapaino Oy, Helsinki.

[34] Statistics Norway (2014) Construction Price Indices and House and Property Price Indices 2006: Results and Methods. Statistics Norway, Oslo.

[35] Wells, J. (2007) Informality in the Construction Sector in Developing Countries. Construction Management and Economics, 25, 87-93.

https://doi.org/10.1080/01446190600601339

[36] Ahadzie, D.K. (2007) A Model for Predicting the Performance of Project Managers in Mass House Building Projects in Ghana. Thesis PhD, University of Wolverhampton, Wolverhampton. 
[37] Akintoye, S.A. (1991) Construction Tender Price Index: Modelling and Forecasting Trends. PhD Thesis, University of Salford, Salford.

[38] Brook, D.E. (1985) Building Cost Index. How It Works and How to Use It. BER Building Survey, 21, 5-18.

[39] Steyn, A.G.W., Smit, C.F., Du Toit, S.H. and Strasheim, C. (2007) Modern Statistics in Practice. 7th Edition, Van Schaik Publishers, Pretoria.

[40] Ferry, D.J., Brandon, P.S. and Ferry, J.D. (2003) Cost Planning of Buildings. 7th Edition, Blackwell Publishing, Oxford.

[41] Kirkham, R. (2007) Ferry and Brandon's Cost Planning of Buildings. 8th Edition, Blackwell Publishing, Oxford.

[42] Ghana Statistical Service. https://www.statsghana.gov.gh

[43] Marx, H.J. (2005) Correctness of the BER Building Cost Index. Research Report, Department of Quantity Surveying and Construction Management, University of the Free State, Bloemfontein.

[44] International Labour Organisation (2004) An Introduction of Consumer Price Index Methodology. Geneva.

[45] Akanni, P.O., Oke, A.E. and Omotilewa, O.J. (2014) Implications of Rising Cost of Building Materials in Lagos State Nigeria. SAGE Open, 4, 1-7. https://doi.org/10.1177/2158244014561213

[46] Seeley, I.H. (1996) Building Economics. 4th Edition, Macmillan Press, London. https://doi.org/10.1007/978-1-349-13757-2

[47] Adobor, D.C. (2013) Framework for Development of Construction Cost Indices Using Unit Rate. MSc Unpublished Thesis, The Department of Building Technology, Kwame Nkrumah University of Science and Technology, Kumasi.

[48] Mkenda, A.F. and Ngasamiaku, W. (2009) An Analysis of Alternative Weighting System on the National Price Index in Tanzania: The Implication to Poverty Analysis. Botswana Journal of Economics, 6, 50-70. https://doi.org/10.4314/boje.v6i10.60208

[49] Cruywagen, J.H.H. (2015) Towards the Establishment of a Relevant Tender-Price Index for the South African Building Industry. Doctoral Dissertation, University of Pretoria, Pretoria.

[50] Statistics Directorate, European Union (1997) Sources and Methods: Construction Price Indices. Statistical Office of the European Community, Luxembourg.

[51] Segalla, U. (1991) The BER Building Cost Index-An Overview. Journal for Studies in Economics and Econometrics, 15, 43-57. 